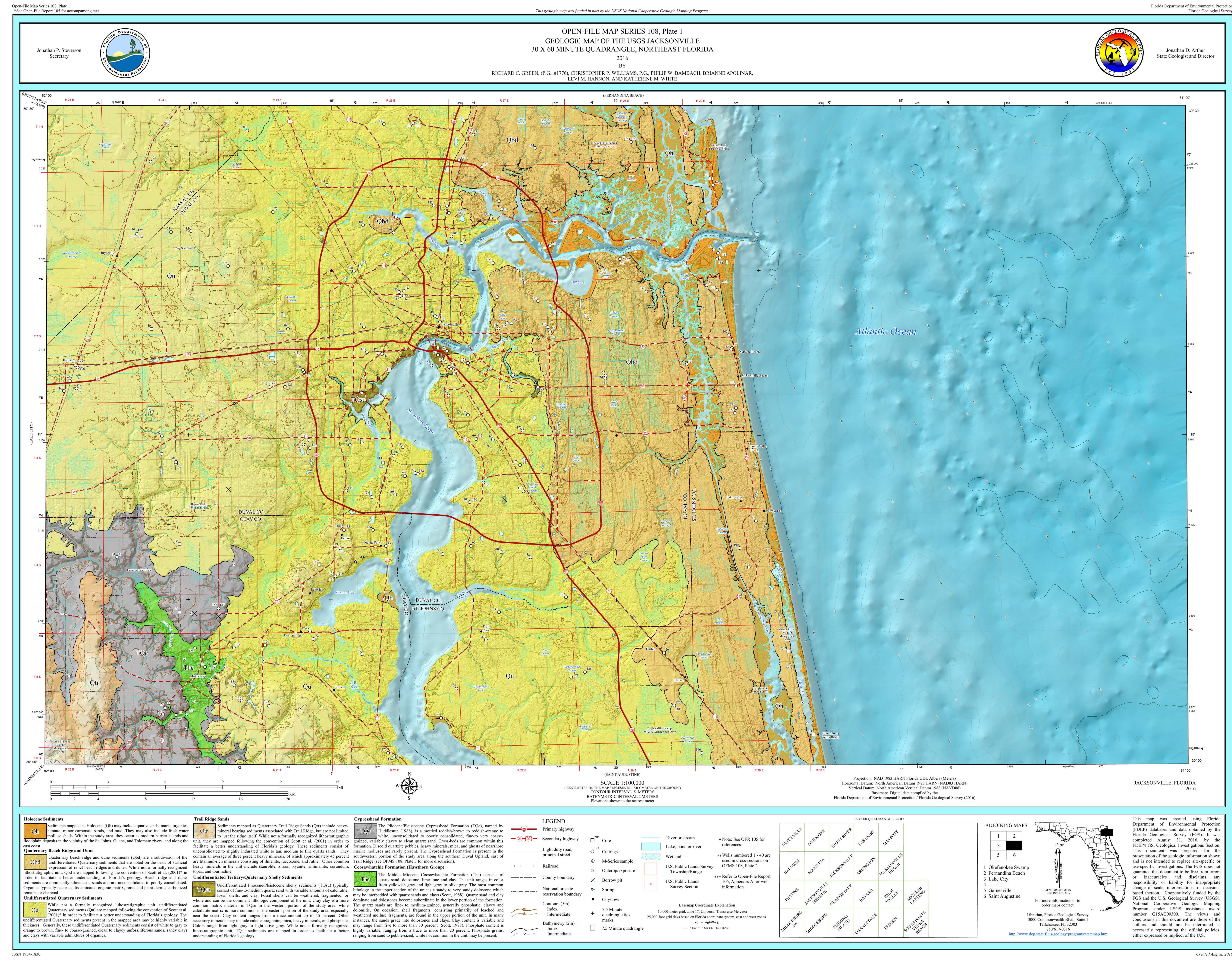




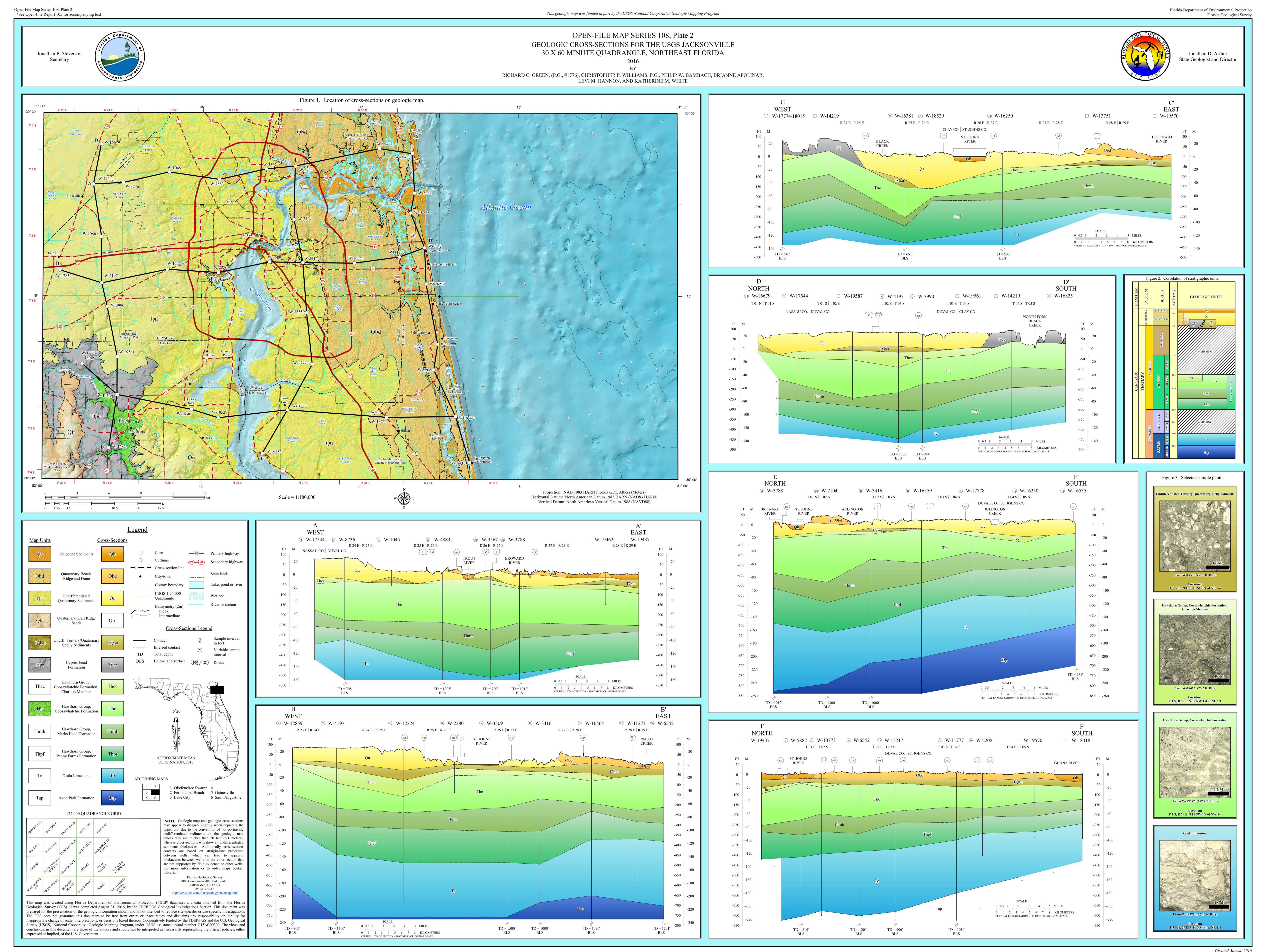




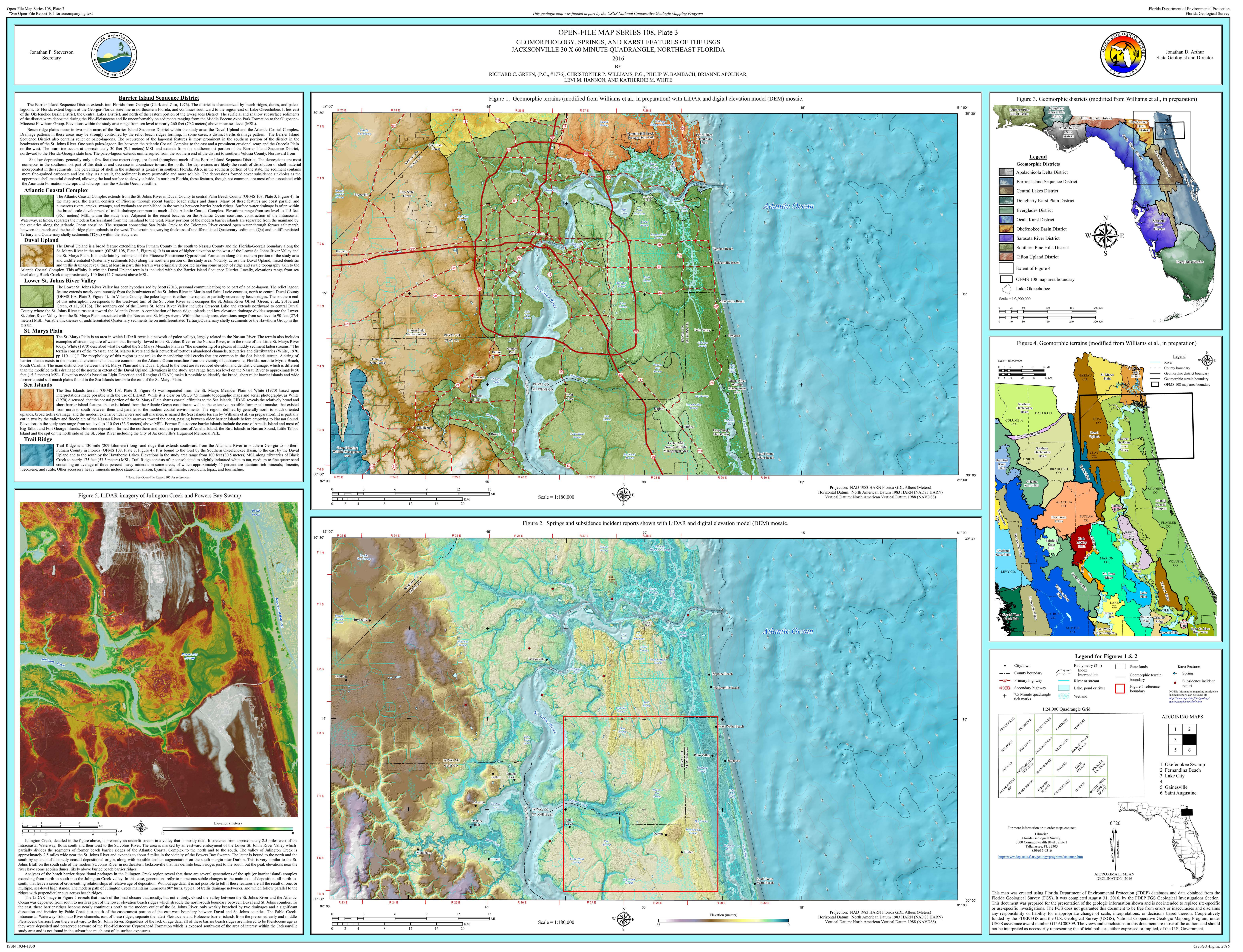




\section{STATE OF FLORIDA}

\section{DEPARTMENT OF ENVIRONMENTAL PROTECTION \\ Jonathan P. Steverson, Secretary \\ REGULATORY PROGRAMS \\ Paula Cobb, Deputy Secretary}

FLORIDA GEOLOGICAL SURVEY

Jonathan D. Arthur, State Geologist and Director

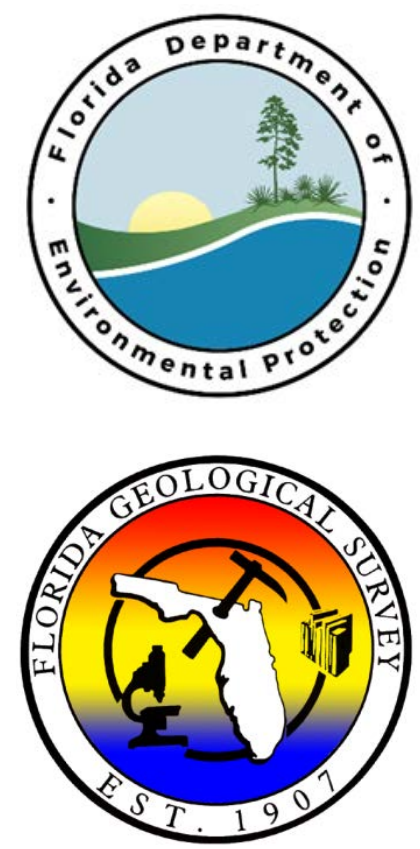

OPEN-FILE REPORT 105

Text to accompany geologic map of the USGS Jacksonville 30 x 60 minute quadrangle, Northeast Florida (Open-File Map Series 108)

By

Richard C. Green, Christopher P. Williams, P.G., Philip W. Bambach, Brianne Apolinar, Levi M. Hannon, and Katherine M. White

2016

ISSN 1058-1391

This geologic map was funded in part by the USGS National Cooperative Geologic Mapping Program under assistance award number G15AC00309 in Federal fiscal year 2015 


\section{TABLE OF CONTENTS}

List of Figures..........................................................................................................................ii

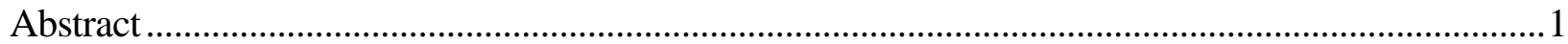

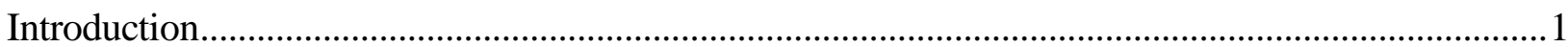

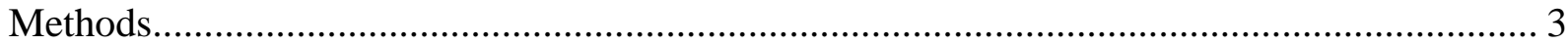

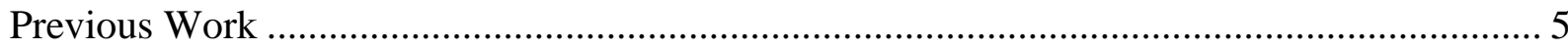

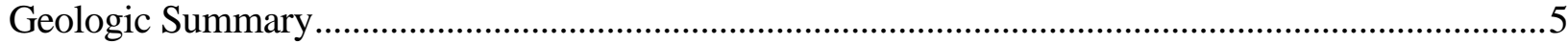

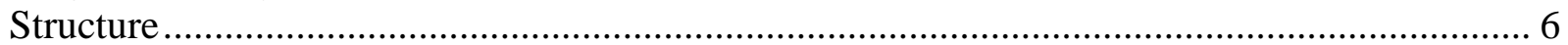

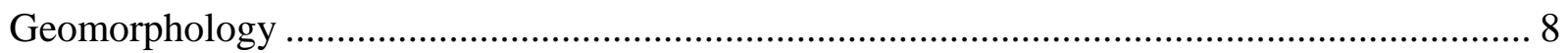

Barrier Island Sequence District ............................................................................................ 9

Atlantic Coastal Complex ........................................................................................... 9

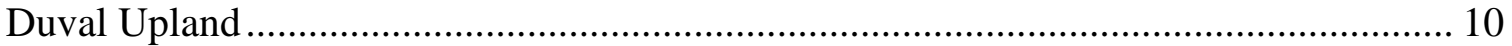

Lower St. Johns River Valley ……………………….............................................. 10

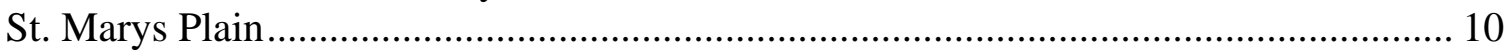

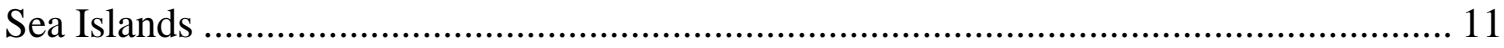

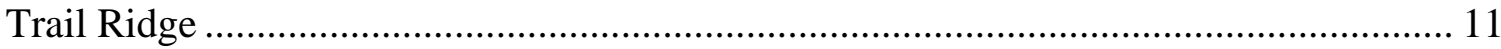

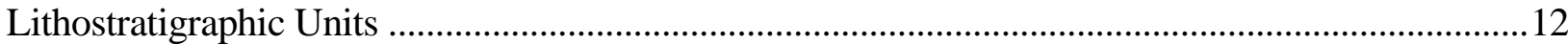

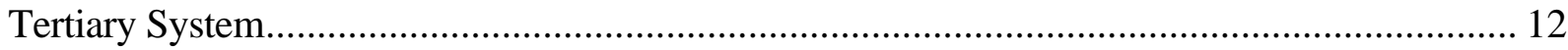

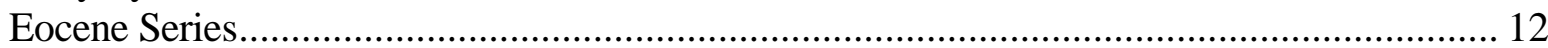

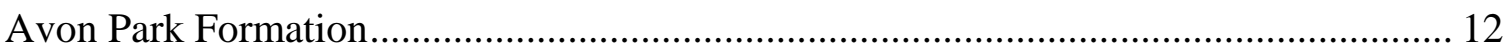

Ocala Limestone ............................................................................................... 13

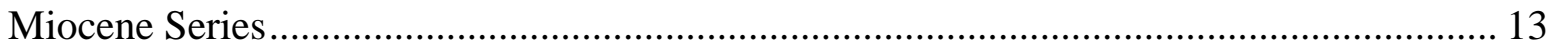

Hawthorn Group ........................................................................................................ 13

Penney Farms Formation ..................................................................................... 14

Marks Head Formation ......................................................................................... 14

Coosawhatchie Formation …………………………….............................................. 15

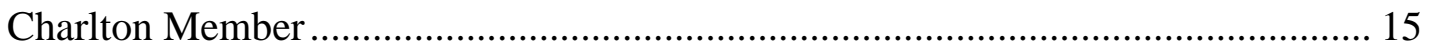

Tertiary/Quaternary Systems............................................................................................... 16

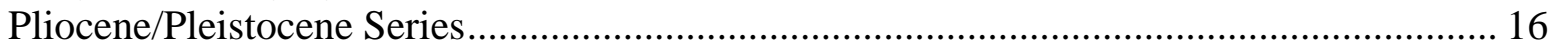

Cypresshead Formation .......................................................................................... 16

Undifferentiated Tertiary/Quaternary Shelly Sediments .................................................. 17

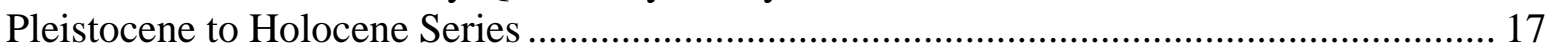

Undifferentiated Quaternary Sediments ............................................................ 17

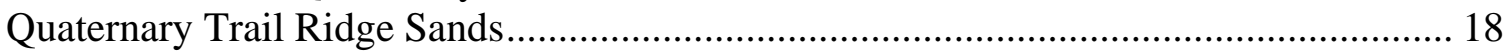

Quaternary Beach Ridge and Dune............................................................................ 18

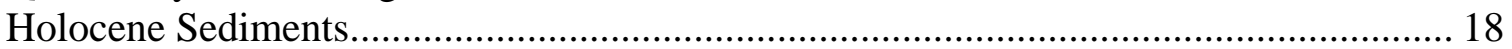

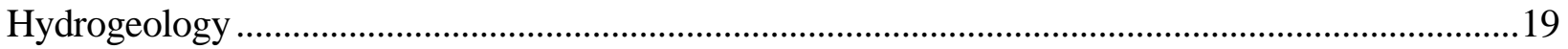

Geophysical Logging .................................................................................................................19

Stratigraphy and Gamma-Ray Log Interpretation ................................................................. 20

Cypresshead Formation ............................................................................................ 20

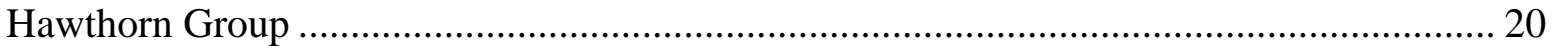

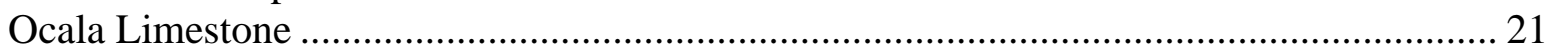

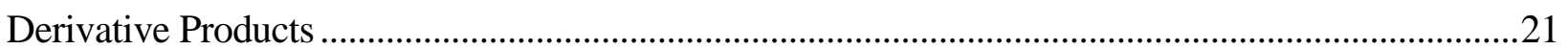

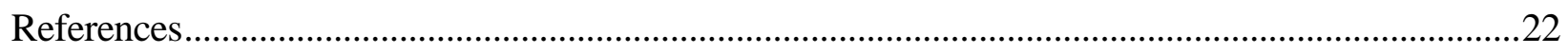

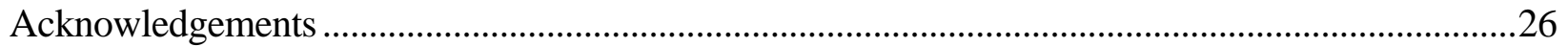

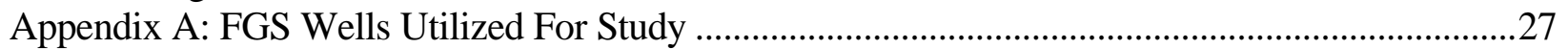




\section{LIST OF FIGURES}

Figure 1. Nearby areas mapped under the FGS STATEMAP Program. ................................... 2

Figure 2. FGS cores (squares) and cuttings (circles) utilized for project .................................... 4

Figure 3. Location of selected river basins, springs and other water bodies. .............................. 6

Figure 4. Principal subsurface structures of north Florida (modified from Scott, 1988).............. 7

Figure 5. Geomorphic Terrains in the study area (after Williams et al., in preparation).............. 8

Figure 6. Gamma Log of W-14219 (see OFMS 108, plate 2, cross section C-C' and D-D')....... 19 


\title{
Text to accompany geologic map of the USGS Jacksonville 30 x 60 minute quadrangle, Northeast Florida (Open File Map Series 108)
}

\author{
Richard C. Green (P.G. No. 1776), Christopher P. Williams, Philip W. Bambach, Brianne \\ Apolinar, Levi M. Hannon, and Katherine M. White
}

\begin{abstract}
The accompanying 1:100,000 scale geologic map (Open-File Map Series 108, Plate 1) depicts the areal distribution of bedrock and surficial geologic units for the U.S. Geological Survey (USGS) Jacksonville 30 × 60 minute quadrangle. The map was constructed using a combination of field mapping (at 1:24,000 scale), compilation of data from existing maps (various scales), core and cuttings analyses and descriptions, geophysical log analyses, and analyses of various Geographic Information System (GIS) data sources. The resulting data were compiled in ESRI ${ }^{\circledR}$ ArcGIS $^{\circledR}$ ArcMap $^{\mathrm{TM}}$ 10.3.1 software for publication as part of the Florida Geological Survey Open-File Map Series. Mapped units range from Middle Miocene to Quaternary. Important resources in the mapped area include potable groundwater, springs, sand, and clay. Several springs, subsidence features, and other karst features are present in the study area. The geologic maps produced for this area not only provide a greater understanding of the interaction between the geologic units, associated karst, springs and ecosystems, but have utility as a land management tool for economic development, mineral and energy production, and environmental protection for Florida. Examples include designing new construction projects, siting new water supply wells, energy production facilities, waste management and storage facilities, locating sources of mineable resources, and protection of springs, hazard mitigation planning, surface and groundwater quality.

Keywords: Florida, geologic map, Avon Park Formation, Ocala Limestone, Hawthorn Group, Penney Farms Formation, Marks Head Formation, Coosawhatchie Formation, Charlton Member, Cypresshead Formation, geomorphology, hydrogeology, springs, karst, sinkholes, Floridan aquifer system, Clay County, Duval County, Nassau County, St. Johns County, Jacksonville.
\end{abstract}

\section{INTRODUCTION}

Florida Geological Survey (FGS) Open-File Report (OFR) 105 accompanies Open-File Map Series (OFMS) 108, which is comprised of three plates. Plate 1 depicts the near-surface geology of the USGS Jacksonville 30 x 60 minute quadrangle on a digital elevation model (DEM). Plate 2 depicts six geologic cross-sections, a stratigraphic correlation chart, and representative photos for several of the lithologic units in the study area. Plate 3 depicts a geomorphology map, a DEM showing locations of known springs and subsidence featueres, and an inset detail of selected geomorphic features within the study area.

The study area is located along the Atlantic Ocean coastline of Florida (Figure 1). It includes the communities of Jacksonville, Jacksonville Beach, and Orange Park. The quadrangle, which includes portions of Clay, Duval, Nassau and St. Johns Counties, is bounded to the west by the USGS Lake City 30 x 60 minute quadrangle, to the south by the USGS Saint Augustine $30 \mathrm{x}$ 60 minute quadrangle, previously mapped under the STATEMAP program (Green et al., 2014a, 
2014b) and to the north by the USGS Fernandina Beach 30 x 60 minute quadrangle (Figure 1). The Arlington, Broward, Guana, St. Johns, St. Marys, Tolomato and Trout rivers, along with several creeks and springs, occur in the map area (OFMS 108, Plate 1).

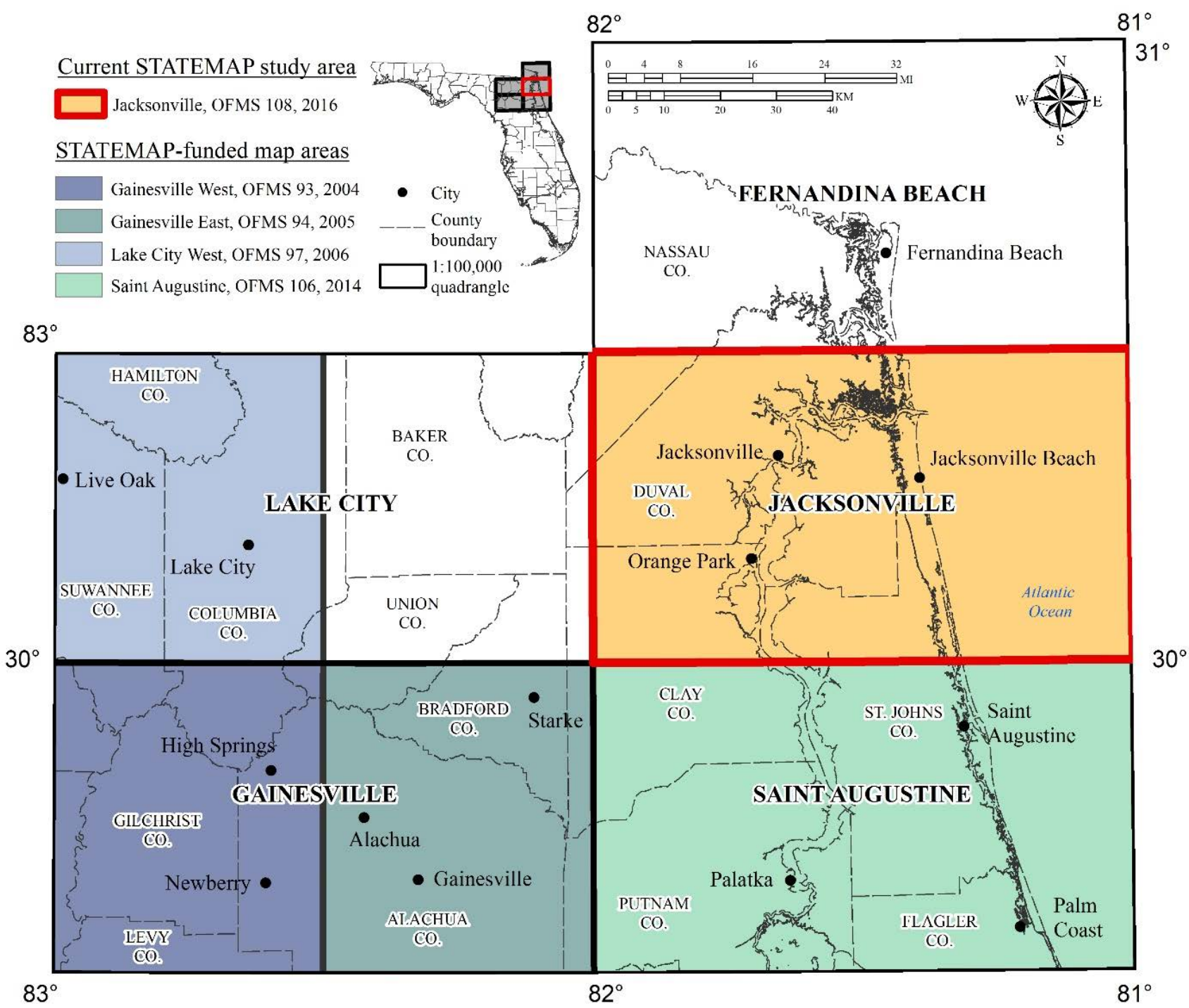

Figure 1. Nearby areas mapped under the FGS STATEMAP Program.

One objective for this report is to provide basic geologic information for the accompanying OFMS 108. Information provided by this report and the plates in OFMS 108 is intended for a diverse audience of professionals in geology, hydrology, engineering, environmental and urban planning, and laypersons, all of whom have varying levels of geologic knowledge. The maps can help users identify and interpret geologic features which impact activities related to groundwater quality and quantity, as well as aid in locating mineral resources, land-use planning and construction project design. Applied uses of the maps and data in this report include: 1) identifying potential new mineral resources, 2) characterizing zones of potential aquifer recharge and confinement, 3) aiding water-management decisions on groundwater flow and usage, 4) providing information on aquifer vulnerability to potential pollution, 5) ecosystem, wetlands and environmental characterization, 6) hazard mitigation planning, and 7) recreation. 


\section{Methods}

Mapping efforts consisted of: 1) compiling and reviewing existing geologic literature and data, 2) mapping geologic units in the field at 1:24,000 scale using standard techniques, 3) analyses of existing core and cuttings samples from the FGS sample repository, 4) new core drilling and analyses, 5) collecting and describing outcrop samples, and 6) preparing a geologic map, geological cross-sections and geomorphic map of the area. Fieldwork, performed during the fall of 2015 through the summer of 2016, consisted of sampling and describing numerous outcrops, river and borrow-pit exposures, and drilling of new cores.

Fifteen new samples of geologic material were added to the FGS surface-sample archives (M-Series) and three cores (989.5 feet or 301.6 meters total) were drilled for the project. Approximately 40 outcrops and exposures were also examined during the project. In addition to new cores collected for this study, approximately 200 sets of cores and cuttings archived in the Florida Geological Survey sample repository were examined and formation contacts were picked for mapped geologic units. Appendix A includes FGS wells with core and/or cuttings samples which were examined by the authors, used for formation surface models, or for determining the geologic surface and subsurface formations. Interpolated surface models were developed using kriging along with a Digital Elevation Model (DEM) to generate an overburden thickness model for several units. The map and accompanying plates were developed in ESRI ${ }^{\circledR} \operatorname{ArcGIS}^{\circledR} \operatorname{ArcMap}^{\mathrm{TM}}$ 10.3 software for publication as part of OFMS 108.

Due to a lack of complete LiDAR coverage in the study area, a custom elevation model was created for this product. Two products were used to create this elevation model: a standard LiDAR elevation model with horizontal resolutions of five feet (1.5 meters), and a much more coarse elevation model, based off of topographic contours, with a horizontal resolution of 100 feet (30.5 meters). LiDAR coverage exists for the entirety of Duval and St. Johns counties, along with the Atlantic coastal shoreline and the St. Johns River valley. Portions of the remaining counties in the study area also had LiDAR available. The majority of both Clay and Nassau counties lacked LiDAR coverage.

The hybrid elevation model was created by first combining all of the existing LiDAR and DEMs into a single raster. The 100 foot (30.5 meter) resolution (contour-based) DEM was resampled and aligned to match the resolution of the five foot (1.5 meter) LiDAR elevation models. A conditional statement was then used in $\mathrm{ESRI}^{\circledR}$ ArcGIS $^{\circledR}$ ArcMap $^{\mathrm{TM}} 10.3$ (ArcGIS) to create a new hybrid raster by selecting an elevation value from the LiDAR coverage if available; where LiDAR was not available, elevation values were drawn from the more coarse, contour-based DEM. The elevation model that was generated by this process created "seams" along the join between the two different elevation models where parallel cells had large differences in their values. Attempts were made to fix the discrepancies by using smoothing techniques to average the cell values along the artifact boundary. Even with various smoothing algorithms applied to the merged dataset, it was not possible to achieve a perfectly smooth transition between the different types of elevation models. Examination of the resultant DEM will reveal one example of this along the border of northern Clay County and southern Duval County (OFMS 108; Plate 3, Figure 2).

Along with the mosaicked elevation model, a bathymetric surface was generated for the Atlantic Ocean and St. Johns River portions of the quadrangle. Bathymetric elevations were derived from NOAA navigational charts at a 1:24,000 scale. USGS five-foot contours, the NOAA bathymetric elevation points, and the Florida Fish and Wildlife Conservation Commission 
shoreline were used in the Topo to Raster tool in ArcGIS to generate an elevation surface. The Topo to Raster tool is primarily designed to map elevation surfaces because of its ability to interpolate contour and point elevations. The tool allows for changes in elevation values that are influenced by terrain changes, making surfaces more characteristic of actual terrain. Once the bathymetric surface was generated, smoothing techniques were used to average the cell values. Bathymetric contours were then generated at two meter intervals.

As a preliminary step for modeling, points from each of the datasets (cores and cuttings) were used to generate a Triangular Irregular Network (TIN) of the surface. This TIN was then used as a method of examining and discarding any points that appeared anomalous compared to their surrounding values. During this step, any point which differed substantially from the surrounding points were indicated by a sharp depression or peak in the TIN surface; points found that differed by 50 or more feet from surrounding points were then removed from the dataset.

An ordinary kriging method was then used to generate a top of rock surface using the "stable" algorithm. Lag size was empirically calculated based on the total spatial extent of the combined datasets, and then adjusted slightly to improve model performance. The error values for all data were examined after each iteration of the model, and any points with a standardized error greater than 30 , or less than negative 30 , were discarded in order to improve the final model performance. The lack of quality samples in the area caused discrepancies among the unit surfaces. With sample intervals as large as 30 feet, a standardized error of 30 or negative 30 helped to alleviate large fluxes of predicted unit surface elevations.

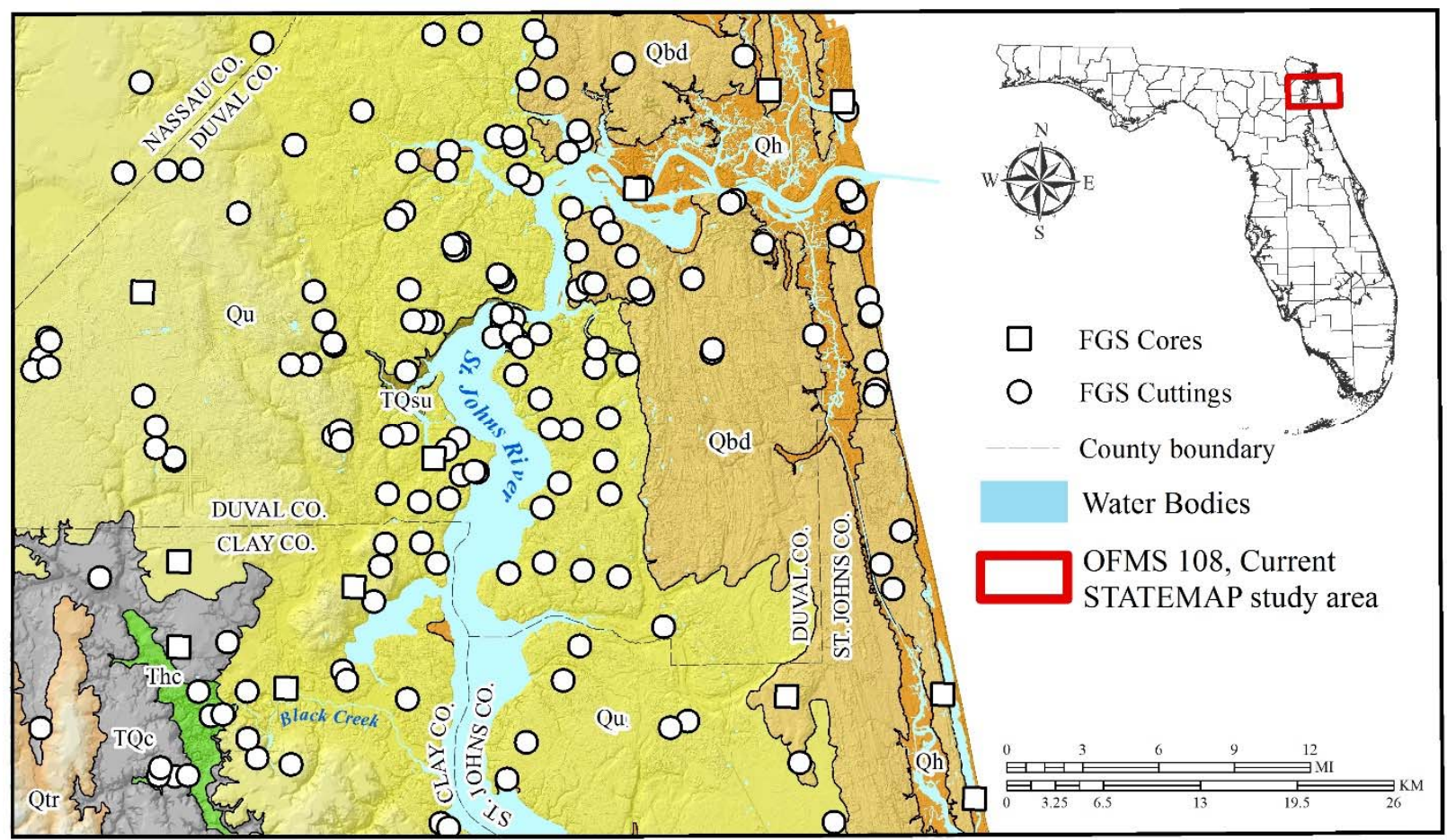

Figure 2. FGS cores (squares) and cuttings (circles) utilized for project. See discussion starting on page 12 for lithostratigraphic unit abbreviations and descriptions.

Much of the study area is blanketed by a veneer of undifferentiated Tertiary and Quaternary sediments and soils. For this reason, and in keeping with geologic mapping practices developed by Scott et al. (2001), the authors have adopted the policy of mapping the first named geologic 
unit within 20 feet (6.1 meters) of the surface. If undifferentiated Quaternary (Qu), Holocene (Qh) or Quaternary beach ridge and dune (Qbd) sediments attain a thickness greater than 20 feet (6.1 meters), then they appear as the mapped unit. If these undifferentiated sediments are less than 20 feet (6.1 meters) thick, then the underlying lithostratigraphic unit appears on the map. It is noted that the geologic map (OFMS 108, Plate 1) and geologic cross sections (OFMS 108, Plate 2) may appear to disagree slightly when depicting the upper unit due to this convention. This is due to the fact that geologic cross-section contacts are based on straight-line projection between wells and thus may lead to apparent thicknesses of units between wells that are not supported by field evidence or other wells nearby.

Parts of the region are heavily vegetated, and access in several large sections of the mapped area was hindered by the presence of numerous wetlands, farms, ranches, and privately owned land. Additionally, much of the coastal area is heavily developed with sub-divisions, many of which are gated communities. In instances where access was limited by these factors, the authors had to rely on existing well and core data. Fieldwork access was typically limited to public roads and Federal, State, and County-owned lands.

\section{Previous Work}

The current study builds on many previous geologic investigations in and around the present map area which were useful in preparing this report. Preliminary county geologic maps for Clay, (Scott, 1992a), Duval, (Scott, 1992b), Nassau, (Scott, 1992c), and St. Johns (Scott, 1992d) counties at 1:126,720 scale were previously published by the FGS. However, each of these geologic maps were constructed in an average time-frame of two weeks utilizing selected in-house geologic data with approximately one week of field work per county. Although these maps provided a starting point for the detailed geologic mapping undertaken for this project, significant refinement of prior geologic maps was possible as a result of this project. A statewide geologic map (Scott et al., 2001) also provided a framework for the current, more detailed mapping.

Scott (1988) published detailed descriptions, structure contour maps, and isopach maps for units of the Hawthorn Group. Huddlestun (1988) defined and discussed the Cypresshead Formation. This study also benefited greatly from the work performed during geologic mapping of the eastern portion of the USGS Gainesville 30 x 60 minute quadrangle (Green et al., 2005) and mapping of the USGS St. Augustine 30 x 60 minute quadrangle (Green et al., 2014a; Green et al., 2014b). Williams et al., (2016, in review) mapped detailed geomorphology and geology for five quadrangles along the eastern edge of the study area as part of work on several National Park Service units in northeastern Florida. A variety of field relationships and stratigraphic problems were worked out during these projects and the data gathered while working on them proved invaluable to the completion of this project.

\section{GEOLOGIC SUMMARY}

The near surface geology of the USGS $30 \times 60$ minute Jacksonville quadrangle is composed of a complex mixture of Middle Eocene to Quaternary carbonate and siliciclastic sediments. A combination of factors, including fluvio-deltaic deposition, marine deposition, dissolution of underlying carbonates (karstification), erosion of sediments as a result of eustatic changes in sea level, and structural features have influenced the geology of the study area.

The oldest unit to crop out in the Jacksonville quadrangle is the Middle Miocene Coosawhatchie Formation of the Hawthorn Group (Thc; Figure 4). Several outcrops were sampled 
along Black Creek and its tributaries (see OFMS 108, Plate 1). Additionally, core and cuttings data indicate that the Tertiary Coosawhatchie Formation of the Hawthorn Group (Thc) is within 20 feet (6.1 meters) of the surface in the vicinity of the north and south forks of Black Creek east of Trail Ridge.

Detailed description of the lithology of all units found in the study area begins on page 12 of this publication. Along with lithologic descriptions, several diagnostic foraminifera and echinoids aided in distinguishing Ocala Limestone from the underlying Avon Park Formation. The Avon Park Formation contains Cushmania [Dictyoconus] americana and Discorinopsis gunteri which were not found in the Ocala Limestone. The occurrence of Nummulites spp. and Lepidocyclina spp. in the Ocala Limestone occasionally helped to distinguish it from the Avon Park Formation in the mapped area.

Much of the Jacksonville quadrangle is located within the Lower St. Johns River Basin, with smaller parts of the mapped area in the Nassau, St. Marys and Upper East Coast River Basins (Figure 3). There are several springs within the study area, including five in Clay County, two in Duval County, and one in Nassau County. Portions of the recharge areas for many of the aforementioned springs are located within the study area. Many of the springs in Florida have shown significant increases in pollutants in the last few decades, particularly nitrate (Scott et al., 2002; Scott, et al., 2004; Upchurch et al., 2004; Copeland et al., 2009). Detailed geologic mapping of lithostratigraphic units in this area provides critical data needed for future assessments of the vulnerability of the aquifer systems and springs to contamination. Understanding the surficial geology of the map area is a key factor in developing management and protection plans, not only for the springs, but for the Floridan aquifer system as well.

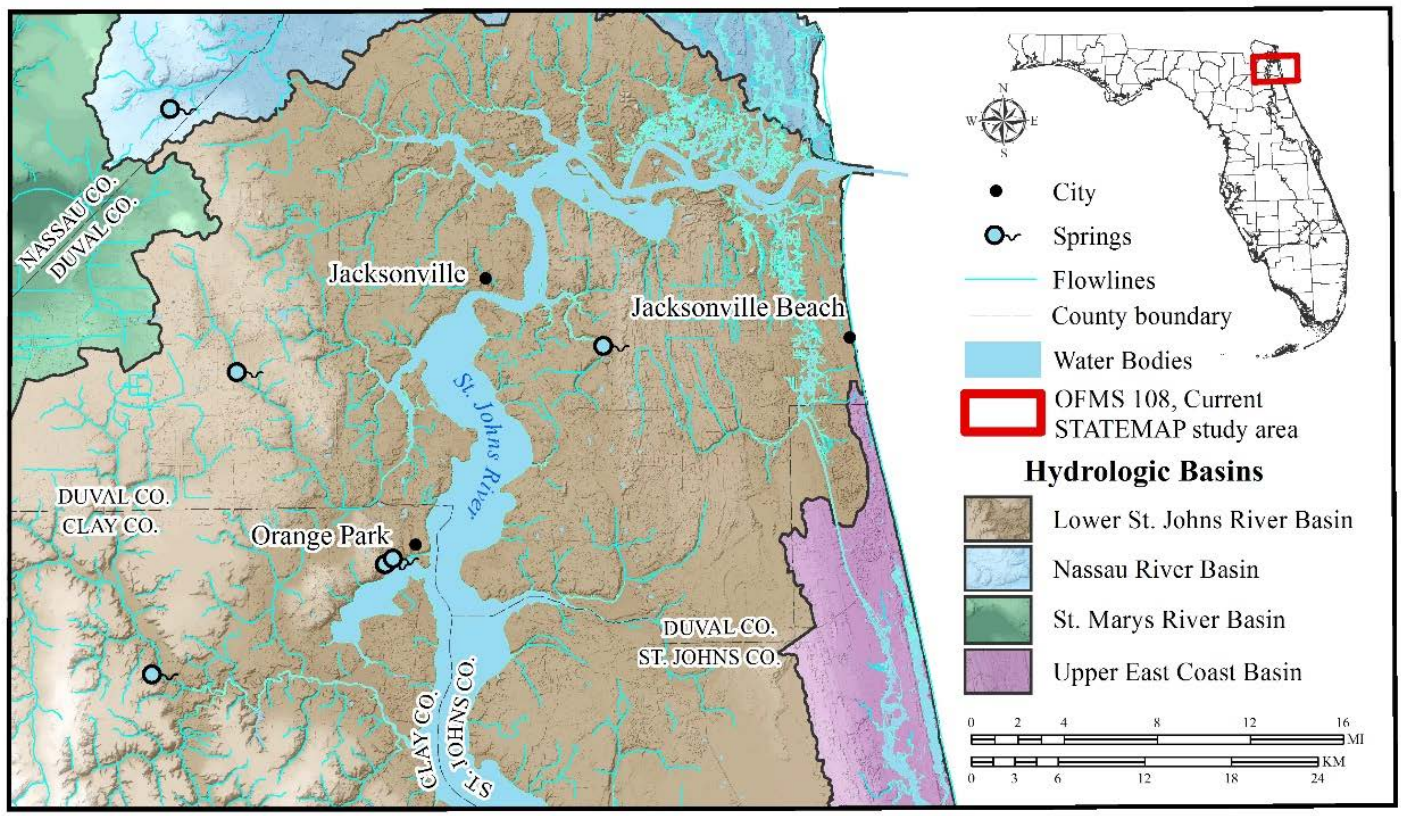

Figure 3. Location of selected river basins, springs and other water bodies.

Structure

Several structural features have affected the geology of the region (Figure 4). The Peninsular Arch, a structurally high area which influenced deposition from the Cretaceous to the 
early Cenozoic, is the dominant subsurface feature of the Florida peninsula (Applin and Applin, 1944; Applin, 1951; Puri and Vernon, 1964; Schmidt, 1984; Miller, 1986; Scott, 1997). The axis of the Peninsular Arch, which lies just west of the study area, extends from southeastern Georgia to the vicinity of Lake Okeechobee in southern Florida and has a northwest to southeast trend. The crest of the arch passes beneath Alachua County and is highest in Columbia and Baker Counties northwest of the study area. The arch was a topographic high during most of the Cretaceous Period and had Upper Cretaceous sediments deposited upon it (Applin, 1951). This feature formed a stable base for Eocene carbonate deposition (Williams et al., 1977). The arch did not affect midTertiary to Holocene sediment deposition (Williams et al., 1977; Scott, 1997).

The St. Johns Platform, introduced by Riggs (1979a, 1979b), extends northward from the Sanford High into St. Johns County just south of the study area. This platform, which is expressed on the erosional surface of the Ocala Limestone, dips gently north-northwest towards the Jacksonville Basin (Scott, 1983).

The Jacksonville Basin, named by Goodell and Yon (1960), is the most prominent low in northeast Florida (Scott, 1988). According to Scott, (1983), this was likely a shallow basin in late Eocene time while the Ocala Limestone was being deposited. The influence of the Jacksonville Basin is evident throughout the map area (OFMS 108; Plate 2). The Hawthorn Group thickens towards the basin which contains over 400 feet (121.9 meters) of Hawthorn Group sediments in the deepest part within the study area (OFMS 108, Plate 2). Leve (1965) thought that the basin was, at least in part, fault controlled.

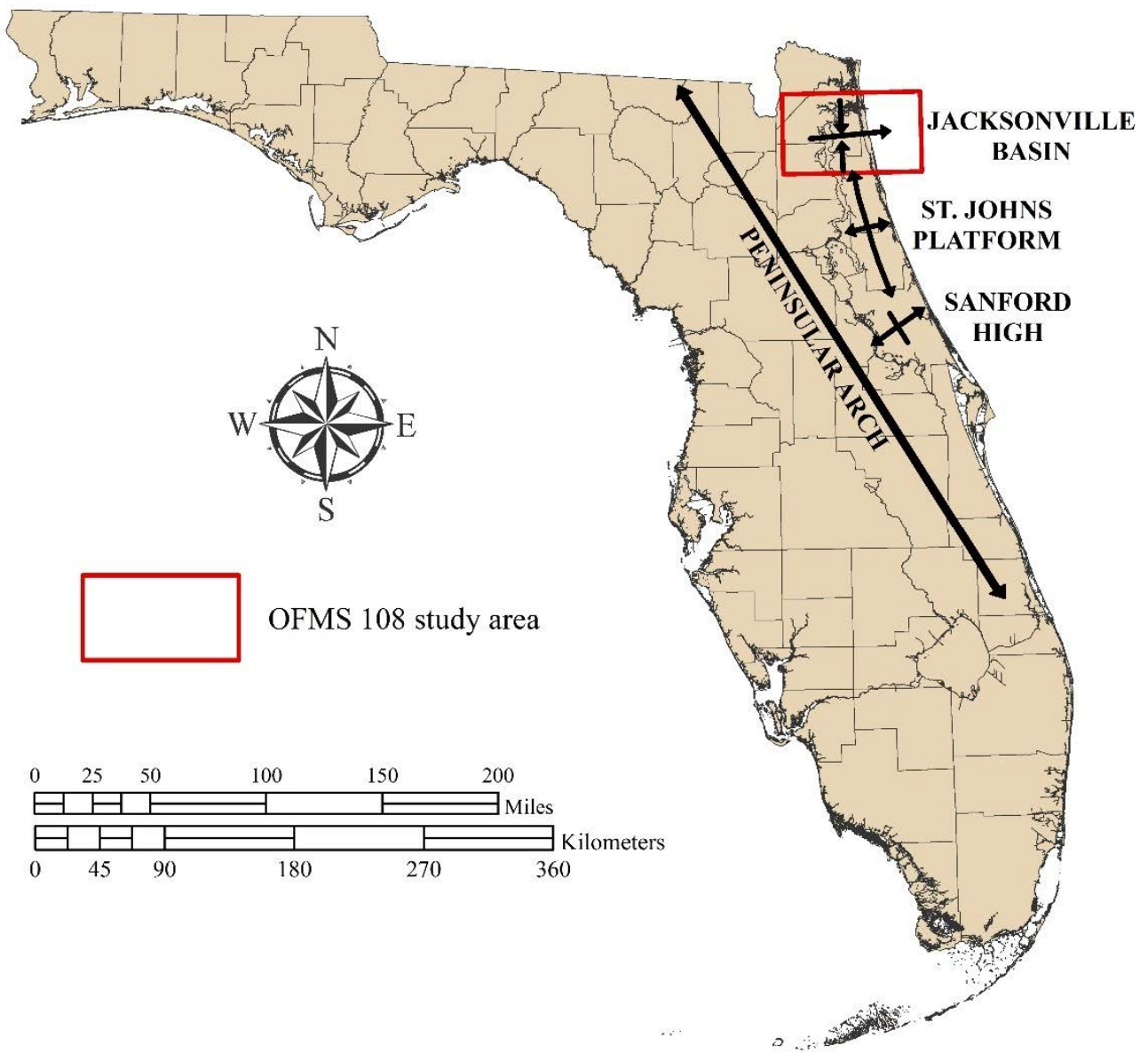

Figure 4. Principal subsurface structures of north Florida (modified from Scott, 1988). 


\section{Geomorphology}

The Florida Geological Survey is producing a new statewide geomorphic map of Florida (Williams et al., in preparation). The new map synthesizes over a century of geomorphic writings and maps about Florida. The Geomorphology of the Florida Peninsula (White, 1970), in addition to significant work by former Assistant State Geologist for Florida, Thomas Scott, are central to the new statewide map. More recent data and technology, particularly the addition of significant coverage of LiDAR data and new possibilities for digital geomorphological mapping that employ spatio-temporal and geocomputational approaches to data, are allowing the FGS to revise nomenclature and refine boundaries for some units in Florida. In the section which follows, all geomorphology unit names and discussions are from Williams et al. (in preparation).

This new map will divide the geomorphology into regional units (districts) and subregional to local units (terrains; Figure 5). Districts are defined by regional groupings in which the geomorphology and near-surface geology are combined to form map polygons that are distinct from adjacent districts. Definition of the more localized terrains and their morphologies are important for the characterization of the districts. Given the prevalence of karst, paleo-shoreline, marine erosion and deposition in Florida, these processes are significant to the identification of both terrains and districts. Several of the northern Florida district names are a continuation of naming conventions used in previous work in Georgia (Clark and Zisa, 1976).

Based on the work of Williams et al., (in preparation), the study area falls within a single geomorphic district: the Barrier Island Sequence District (OFMS 108; Plate 3, Figure 3). This district is further subdivided into six terrains: the Atlantic Coastal Complex, the Duval Upland, the Sea Islands, the Lower St. Johns River Valley, the St. Marys Plain, and Trail Ridge (Figure 5). The geomorphic units listed below are discussed in alphabetical, not geographical, order.

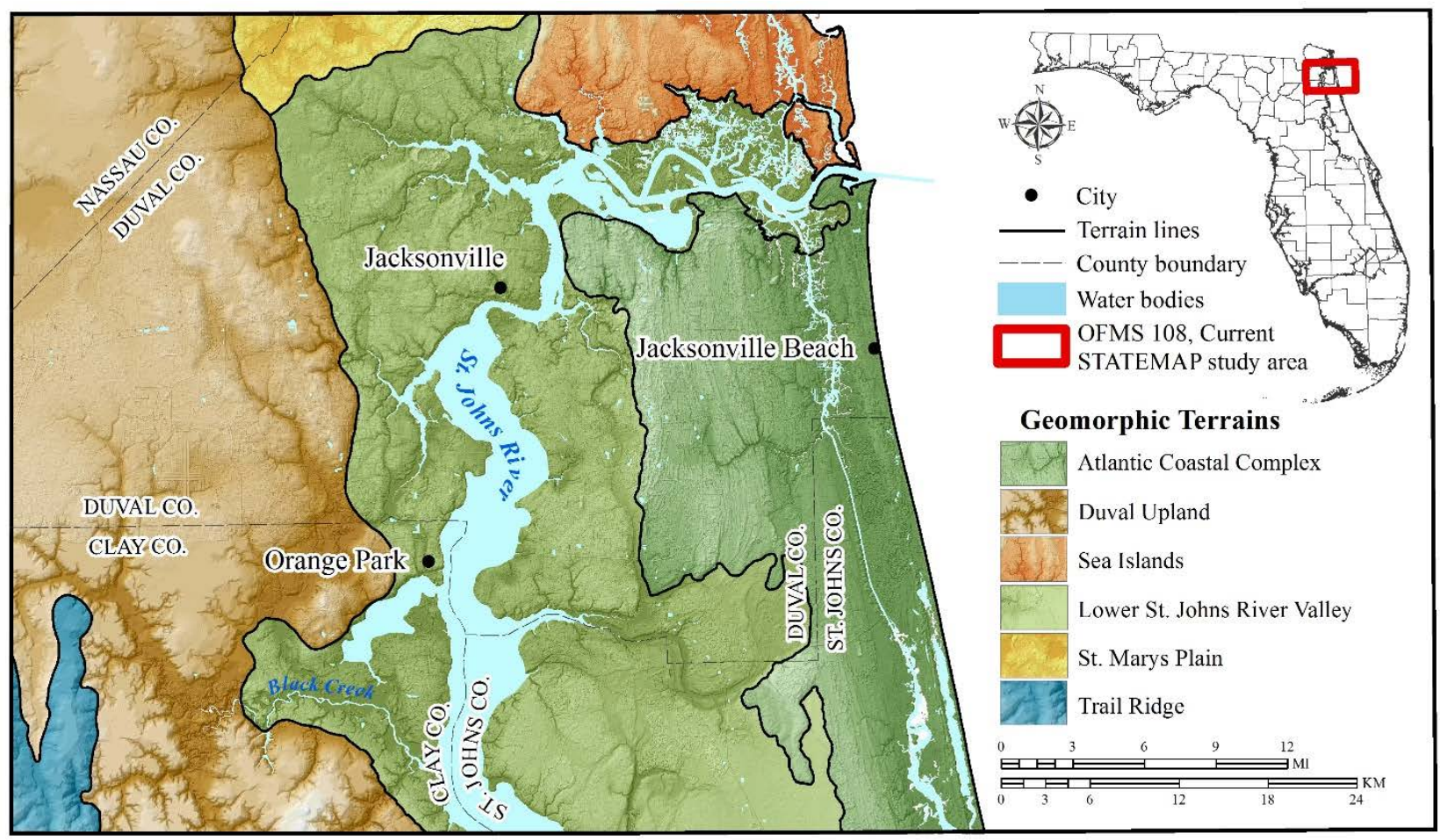

Figure 5. Geomorphic Terrains in the study area (after Williams et al., in preparation). 


\section{Barrier Island Sequence District}

The Barrier Island Sequence District extends into Florida from Georgia (Clark and Zisa, 1976). The district is characterized by beach ridges, dunes, and paleo-lagoons. Its Florida extent begins at the Georgia-Florida state line in northeastern Florida, and continues southward to the region east of Lake Okeechobee. It lies east of the Okefenokee Basin District, the Central Lakes District, and north of the eastern portion of the Everglades District. The surficial and shallow subsurface sediments of the district were deposited during the Plio-Pleistocene and lie unconformably on sediments ranging from the Middle Eocene Avon Park Formation to the Oligocene-Miocene Hawthorn Group. Elevations within the study area range from sea level to nearly 260 feet (79.2 meters) above mean sea level (MSL).

Beach ridge plains occur in two main areas of the Barrier Island Sequence District within the study area: the Duval Upland and the Atlantic Coastal Complex. Drainage patterns in these areas may be strongly controlled by the relict beach ridges forming, in some cases, a distinct trellis drainage pattern. The Barrier Island Sequence District also contains relict or paleo-lagoons. The occurrence of the lagoonal features is most prominent in the southern portion of the district in the headwaters of the St. Johns River. One such paleo-lagoon lies between the Atlantic Coastal Complex to the east and a prominent erosional scarp and the Osceola Plain on the west. The scarp toe occurs at approximately 30 feet (9.1 meters) MSL and extends from the southernmost portion of the Barrier Island Sequence District, northward to the Florida-Georgia state line. The paleolagoon extends uninterrupted from the southern end of the district to southern Volusia County. Northward from southern Volusia County, the relict lagoon is either interrupted or partially covered by beach ridges. The lagoon can be recognized from southern Flagler County to as far north as the vicinity of Jacksonville.

Shallow depressions, generally only a few feet (one meter) deep, are found throughout much of the Barrier Island Sequence District. The depressions are most numerous in the southernmost part of this district and decrease in abundance toward the north. The depressions are likely the result of dissolution of shell material incorporated in the sediments. The percentage of shell in the sediment is greatest in southern Florida. Also, in the southern portion of the state, the sediment contains more fine-grained carbonate and less clay. As a result, the sediment is more permeable and more soluble. The depressions formed cover subsidence sinkholes as the uppermost shell material dissolved, allowing the land surface to slowly subside. In northern Florida, these features, though not common, are most often associated with the Anastasia Formation outcrops and subcrops near the Atlantic Ocean coastline.

\section{Atlantic Coastal Complex}

The Atlantic Coastal Complex extends from the St. Johns River in Duval County to central Palm Beach County (OFMS 108, Plate 3, Figure 4). In the map area, the terrain consists of Pliocene through recent barrier beach ridges and dunes. Many of these features are coast parallel and numerous rivers, creeks, swamps, and wetlands are established in the swales between barrier beach ridges. Surface water drainage is often within the broad scale development of trellis drainage

common to much of the Atlantic Coastal Complex. Elevations range from sea level to 115 feet (35.1 meters) MSL within the study area. Adjacent to the recent beaches on the Atlantic Ocean coastline, construction of the Intracoastal Waterway, at times, separates the modern barrier island 


\section{FLORIDA GEOLOGICAL SURVEY}

from the mainland to the west. Many portions of the modern barrier islands are separated from the mainland by the estuaries along the Atlantic Ocean coastline. The segment connecting San Pablo Creek to the Tolomato River created open water through former salt marsh between the beach and the beach ridge plain uplands to the west. The terrain has varying thickness of undifferentiated Quaternary sediments (Qu) and undifferentiated Tertiary and Quaternary shelly sediments (TQsu) within the study area.

\section{Duval Upland}

The Duval Upland is a broad feature extending from Putnam County in the south to Nassau County and the Florida-Georgia boundary along the St. Marys River in the north (OFMS 108, Plate 3, Figure 4). It is an area of higher elevation to the west of the Lower St. Johns River Valley and the St. Marys Plain. It is underlain by sediments of the Pliocene-Pleistocene Cypresshead Formation along the southern portion of the study area and undifferentiated Quaternary sediments (Qu) along the northern portion of the study area. Notably, across the Duval Upland, mixed dendritic and trellis drainage reveal that, at least in part, this terrain was originally deposited having some aspect of ridge and swale topography akin to the Atlantic Coastal Complex. This affinity is why the Duval Upland terrain is included within the Barrier Island Sequence District. Locally, elevations range from sea level along Black Creek to approximately 140 feet (42.7 meters) above MSL.

\section{Lower St. Johns River Valley}

The Lower St. Johns River Valley has been hypothesized by Scott (2013, personal communication) to be part of a paleo-lagoon. The relict lagoon feature extends nearly continuously from the headwaters of the St. Johns River in Martin and Saint Lucie counties, north to central Duval County (OFMS 108, Plate 3, Figure 4). In Volusia County, the paleo-lagoon is either interrupted or partially covered by beach ridges. The southern end of this interruption corresponds to the westward turn of the St. Johns River as it occupies the St. Johns River Offset (Green, et al., 2013a and Green, et al., 2013b). The southern end of the Lower St. Johns River Valley includes Crescent Lake and extends northward to central Duval County where the St. Johns River turns east toward the Atlantic Ocean. A combination of beach ridge uplands and low elevation drainage divides separate the Lower St. Johns River Valley from the St. Marys Plain associated with the Nassau and St. Marys rivers. Within the study area, elevations range from sea level to 90 feet (27.4 meters) MSL. Variable thicknesses of undifferentiated Quaternary sediments lie on undifferentiated Tertiary/Quaternary shelly sediments or the Hawthorn Group in the terrain.

$$
\text { St. Marys Plain }
$$

The St. Marys Plain is an area in which LiDAR reveals a network of paleo valleys, largely related to the Nassau River. The terrain also includes examples of stream capture of waters that formerly flowed to the St. Johns River or the Nassau River, as in the route of the Little St. Marys River today. White (1970) described what he called the St. Marys Meander Plain as "the meandering of a plexus of muddy sediment laden streams." The terrain consists of the "Nassau and St. Marys Rivers and their network of tortuous abandoned channels, tributaries and distributaries (White, 1970, pp 110-111)." The morphology of this region is not unlike the 
meandering tidal creeks that are common in the Sea Islands terrain. A string of barrier islands exists in the mesotidal environments that are common on the Atlantic Ocean coastline from the vicinity of Jacksonville, Florida, north to Myrtle Beach, South Carolina. The main distinctions between the St. Marys Plain and the Duval Upland to the west are its reduced elevation and dendritic drainage, which is different than the modified trellis drainage of the northern extent of the Duval Upland. Elevations in the study area range from sea level on the Nassau River to approximately 50 feet (15.2 meters) MSL. Elevation models based on Light Detection and Ranging (LiDAR) make it possible to identify the broad, short relict barrier islands and wide former coastal salt marsh plains found in the Sea Islands terrain to the east of the St. Marys Plain.

\section{Sea Islands}

The Sea Islands terrain (OFMS 108, Plate 3, Figure 4) was separated from the St. Marys Meander Plain of White (1970) based upon interpretations made possible with the use of LiDAR. While it is clear on USGS 7.5 minute topographic maps and aerial photography, as White (1970) discussed, that the coastal portion of the St. Marys Plain shares coastal affinities to the Sea Islands, LiDAR reveals the relatively broad and short barrier island features that exist inland from the Atlantic Ocean coastline as well as the extensive, possible former salt marshes that existed from north to south between them and parallel to the modern coastal environments. The region, defined by generally north to south oriented uplands, broad trellis drainage, and the modern extensive tidal rivers and salt marshes, is named the Sea Islands terrain by Williams et al. (in preparation). It is partially cut in two by the valley and floodplain of the Nassau River which narrows toward the coast, passing between older barrier islands before emptying to Nassau Sound. Elevations in the study area range from sea level to 110 feet (33.5 meters) above MSL. Former Pleistocene barrier islands include the core of Amelia Island and most of Big Talbot and Fort George islands. Holocene deposition formed the northern and southern portions of Amelia Island, the Bird Islands in Nassau Sound, Little Talbot Island and the spit on the north side of the St. Johns River including the City of Jacksonville’s Huguenot Memorial Park.

\section{Trail Ridge}

Trail Ridge is a 130-mile (209-kilometer) long sand ridge that extends southward from the Altamaha River in southern Georgia to northern Putnam County in Florida (OFMS 108, Plate 3, Figure 4). It is bound to the west by the Southern Okeefenokee Basin, to the east by the Duval Upland and to the south by the Hawthorne Lakes. Elevations in the study area range from 100 feet (30.5 meters) MSL along tributaries of Black Creek to nearly 175 feet (53.3 meters) MSL. Trail Ridge consists of unconsolidated to slightly indurated white to tan, medium to fine quartz sand containing an average of three percent heavy minerals in some areas, of which approximately 45

percent are titanium-rich minerals; ilmenite, luecoxene, and rutile. Other accessory heavy minerals include staurolite, zircon, kyanite, sillimanite, corundum, topaz, and tourmaline. 


\title{
LITHOSTRATIGRAPHIC UNITS
}

\author{
Tertiary System
}

\section{Eocene Series}

\author{
Avon Park Formation
}

The Middle Eocene Avon Park Formation (Tap), first described by Applin and Applin (1944), is a subsurface unit within the USGS Jacksonville 30 x 60 minute quadrangle. It was encountered in many of the wells utilized for this study and efforts were made to include it in the geologic cross sections where suitable well coverage existed (see OFMS 108, Plate 2).

The lithology of the Avon Park Formation varies between limestone and dolostone. The limestones consist of cream to light brown to tan, poorly to well indurated, variably fossiliferous grainstone and wackestone, with rare mudstone. The limestones are often interbedded with tan to brown, very poorly to well indurated, very fine to medium crystalline, fossiliferous (molds and casts), vuggy dolostones. Minor clay beds and organic-rich laminations may occur, especially at or near the top of the unit. Accessory minerals include chert, pyrite, celestine, gypsum and quartz (some as doubly-terminated euhedral crystals "floating" in vugs).

Fossils present in the unit include molluscs, foraminifera (Spirolina sp., Lituonella floridana, Bolivina spp., Cushmania [Dictyoconus] americana), Cribrobulimina cushmani, and Fabiana cubensis, echinoids (Neolaganum [Peronella] dalli), algae and carbonized plant remains. Porosity in the Avon Park Formation is generally intergranular in the limestone section. Fracture porosity occurs in the more densely recrystallized dolostone and intercrystalline porosity is characteristic of sucrosic textures. Pinpoint vugs and fossil molds are present to a lesser extent.

Throughout most of the study area, the boundary between the Middle Eocene Avon Park Formation and the unconformably overlying Upper Eocene Ocala Limestone, is marked by a moderately to highly recrystallized, thin, pale brown dolostone at the top of the Avon Park. It contrasts distinctly with the foraminifera-rich Ocala Limestone (grainstone to packstone), making the contact relatively easy to discern even in cuttings. The fossil fauna in this area were only somewhat helpful in determining the contact. This contrasts with the Orlando Quadrangle to the south (Green, et al., 2015a; Green et al., 2015b), where the contact was more easily determined due to textural changes in the grain and matrix of the limestones, in addition to a more abrupt change in fossil fauna from benthic forams, mollusks and gastropods to the cone-shaped foram Cushmania [Dictyoconus] americana.

The top of the Avon Park Formation is generally deeper than most borehole samples in the area. Therefore, the total thickness of the Avon Park Formation was not investigated in this study. The top of the Avon Park ranges from approximately 494 feet (150.6 meters) below MSL in W16535 (OFMS 108; Plate 2, cross-section E-E') to approximately 827 feet (252.1 meters) below MSL in W-3788 (OFMS 108; Plate 2, cross-sections A-A' and E-E'). The Avon Park Formation forms part of the FAS (Southeastern Geological Society Ad Hoc Committee on Florida Hydrostratigraphic Unit Definition, 1986). 


\section{Ocala Limestone}

The Upper Eocene Ocala Limestone (To), first described by Dall and Harris (1892), is a biogenic marine limestone comprised largely of foraminifera, molluscs, echinoids and bryozoans. The Ocala Limestone sits unconformably on the Avon Park Formation throughout the study area.

Based on lithologic differences, the Ocala Limestone can be informally subdivided into an upper and lower unit (Scott, 1991). This subdivision, while often apparent in cores and quarries, is not readily apparent in cuttings. As a consequence of this, the geologic cross-sections do not break out the upper and lower Ocala Limestone. The upper unit is typically a white to cream, fine to coarse grained, poorly to well indurated, moderately- to well-sorted, very fossiliferous limestone (wackestone, packstone, and grainstone). Fossils commonly include foraminifera, bryozoans, molluscs, and a rich diversity of echinoids. The lower unit is typically a white to cream, fine- to medium-grained, poorly to moderately indurated, moderately- to well-sorted limestone (grainstone to packstone). Fossils include foraminifera (Lepidocyclina ocalana, Amphistegina pinarensis, Nummulites [Camerina] vanderstoki, Nummulites [Operculinoides] ocalana), bryozoans, algae, molluscs, echinoids, and crustaceans.

The Ocala Limestone occurs throughout the study area, is highest along the southern portion of the map area, and deepens towards the central portion of the study area in the Jacksonville Basin (OFMS 108, Plate 2). The top of the Ocala Limestone ranges from 243 feet (74.1 meters) below MSL in W-18418, (OFMS 108; Plate 2, cross-section F-F') to 536 feet (163.4 meters) below MSL in W-7104 (OFMS 108; Plate 2, cross-sections E-E'). In these wells, the thickness of the Ocala Limestone ranges from 190 feet (57.9 meters) in W-3416 (OFMS 108; Plate 2, cross-section B-B' and E-E') to 337 feet (102.7 meters) in W-3788 (OFMS 108; Plate 2, crosssection A-A' and E-E'). The Ocala Limestone forms part of the FAS (Southeastern Geological Society Ad Hoc Committee on Florida Hydrostratigraphic Unit Definition, 1986).

\section{Miocene Series}

\section{Hawthorn Group}

Sediments of the Miocene Hawthorn Group are thickest in the Jacksonville Basin (Scott, 1983; Scott, 1988). Hawthorn Group sediments within the study area consist of phosphatic siliciclastics (sands, silts, and clays) and carbonates (dolostone with minor limestone). Fossils in the Hawthorn Group are sparse but may include vertebrates, corals, miliolids, and molluscs. Benthic foraminifera characteristic of the Hawthorn Group include Archaias spp. and Sorites sp.

Within the mapped area, the Hawthorn Group is composed of (in ascending order) the Penney Farms Formation (Thpf), the Marks Head Formation (Thmh), the Coosawhatchie Formation (Thc), and the Charlton Member of the Coosawhatchie Formation (Thcc; OFMS 108, Plate 2, Figure 2). While these units can be identified and delineated in cores, they often can be difficult to differentiate in cuttings, particularly where cavings or large sample intervals cause mixing of the sediments during drilling. After much effort, the authors were able to break out the units on cross-section wells; however, the contacts were often uncertain in wells with larger sample intervals, and are therefore dashed.

Unit descriptions for the Hawthorn Group listed below are summaries and the reader is referred to Scott (1988) for a more complete discussion of lithologies, variability, and relationships of these lithologically complex formations. Hawthorn Group sediments are unconformably 
overlain by undifferentiated Pliocene/Pleistocene shelly sediments (TQsu), Cypresshead Formation (TQc), and undifferentiated Quaternary sediments (Qu).

Hawthorn Group sediments occur throughout the mapped area (OFMS 108, Plate 2) and thickens in the Jacksonville Basin. The top of the Hawthorn Group ranges between 44 feet (13.4 meters) above MSL in W-14219 (OFMS 108; Plate 2, cross-section C-C' and D-D') to 156 feet (47.6 meters) below MSL in W-16381 (OFMS 108; Plate 2, cross-section C-C'). The Hawthorn Group sediments range in thickness from 180 feet (54.9 meters) in well W-18418 (OFMS 108; Plate 2, cross-section F-F') to 460 feet (140.2 meters) in well W-3416 (OFMS 108; Plate 2, crosssection B-B' and E-E'). Sediments of the Hawthorn Group form the Intermediate aquifer system/Intermediate confining unit (IAS/ICU; Southeastern Geological Society Ad Hoc Committee on Florida Hydrostratigraphic Unit Definition, 1986).

\section{Penney Farms Formation}

The Lower Miocene Penney Farms Formation (Thpf) consists of variable admixtures of dolostone, quartz sand, phosphatic sand, and clay. The sand content is variable and at times the unit becomes a dolomitic sand. Phosphatic sand is common and may be present in amounts exceeding 25 percent, with an average of 5 to 10 percent (Scott, 1988). Clay percentages are generally minor (less than five percent) and often increase towards the top of the unit in the dolostones. The dolostones are medium gray to pale yellowish brown and are generally moderately- to well-indurated. Mollusc molds are sometimes present in the dolostones. Bored hardgrounds, burrows and intraclasts are common in the hard, finer-grained dolostones in the lower portion of the unit. These intraclasts are composed of dolomite similar to the rest of the unit, but they often have rims of phosphate replacement along the edges of the clasts. This hard, fine-grained dolostone was less commonly observed in the unit than in areas further south (Green, et al, 2013a; Green, et al, 2013b). Limestone, which occurs sporadically in the lower portion of the unit, is generally dolomitic, phosphatic, and contains quartz sand. The Penney Farms Formation unconformably overlies the Ocala Limestone within the mapped area. It is overlain unconformably by the Marks Head Formation (Hawthorn Group). The top of the Penney Farms Formation is placed at the contact between the darker-colored sands and clays of the upper Penney Farms and the lighter-colored interbedded sands, clays, and dolostone of the Marks Head Formation (Scott, 1988). Sediments of the Penney Farms Formation occur throughout the mapped area (OFMS 108, Plate 2). The top of the unit ranges from 122 feet (37.2 meters) above MSL in W-12859 (OFMS 108; Plate 2, cross-section B-B') to 377 feet (114.9 meters) below MSL in W-13567 (OFMS 108; Plate 2, cross-sections A-A'). The Penney Farms Formation ranges in thickness from 52 feet (15.9 meters) in W-18736 (OFMS 108; Plate 2, cross-section A-A') to 135 feet (41.1 meters) in well W3788 (OFMS 108; Plate 2, cross-section A-A').

Marks Head Formation

The Lower Miocene Marks Head Formation (Thmh) consists of interbedded sands, clays, and dolostones. Limestone, while uncommon, does occur within the unit (Scott, 1988). It was observed in concentrations higher than typically expected within the study area. More commonly observed in core, the calcareous component of this unit was present primarily as benthic forams and miliolids which have undergone various states of weathering. Dolostones are generally quartz sandy, phosphatic, and clayey. Colors of the dolostones range from yellowish-gray to olive gray. 
Induration, which varies inversely with the clay content, ranges from poorly consolidated to well indurated. Phosphate content typically ranges up to five percent, but may occasionally be significantly higher. Quartz sand content ranges from five percent to greater than 50 percent. The sands tend to be finer grained than the sands in either the Penney Farms or Coosawhatchie Formations. The unit is overlain unconformably by the Coosawhatchie Formation, although this unconformity is often not readily apparent. In general, the contact between the Coosawhatchie and Marks Head formations is placed at the top of the first hard carbonate bed or light-colored clay unit below the darker-colored, clayey, dolomitic quartz sands and dolostones of the basal Coosawhatchie Formation (Scott, 1988). Sediments of the Marks Head Formation occur throughout the mapped area (OFMS 108, Plate 2). The top of the Marks Head Formation ranges from 80 feet (24.4 meters) below MSL in W-13571 (OFMS 108; Plate 2, cross-section C-C') to 300 feet (91.4 meters) below MSL in W-16381 (OFMS 108; Plate 2, cross-section C-C'). The Marks Head Formation ranges in thickness from 20 feet (6.1 meters) in well W-18529 (OFMS 108; Plate 2, cross-section C-C') to 160 feet (48.8 meters) in well W-3416 (OFMS 108; Plate 2, cross-sections B-B' and E-E').

\section{Coosawhatchie Formation}

The Middle Miocene Coosawhatchie Formation (Thc) consists of quartz sand, dolostone, limestone, and clay. The unit ranges in color from yellowish gray and light gray to olive gray. The most common lithology in the upper section of the unit is a sandy to very sandy dolostone which may be interbedded with quartz sands and clays (Scott, 1988). Quartz sand and clay dominate and dolostones become subordinate in the lower portion of the formation. The quartz sands are fineto medium-grained, generally phosphatic, clayey, and dolomitic. On occasion, shell fragments, consisting primarily of leached and weathered mollusc fragments, are found in the upper portion of the unit. In many instances, the sands grade into dolostones and clays. Clay content is variable and may range from five to more than 30 percent (Scott, 1988). Phosphate content is highly variable, ranging from a trace to more than 20 percent. Phosphate grains, ranging from sand to pebble-sized, while not common in the unit, may be present. The unit crops out along parts of the north and south forks of Black Creek in the southwest portion of the mapped area (OFMS 108, Plates 1 and 2), where it is unconformably overlain by the Pliocene/Pleistocene Cypresshead Formation (TQc). It is unconformably overlain by undifferentiated Pliocene/Pleistocene shelly sediments (TQsu), and undifferentiated Quaternary sediments $(\mathrm{Qu})$ elsewhere in the study area (OFMS 108, Plate 2). The top of the Coosawhatchie Formation ranges between 44 feet (13.4 meters) above MSL in W-14219 (OFMS 108; Plate 2, cross-section C-C' and D-D') to 156 feet (47.6 meters) below MSL in W-16381 (OFMS 108; Plate 2, cross-section C-C'). The Coosawhatchie Formation, which includes the Charlton Member discussed below, ranges in thickness from 40 feet (12.2 meters) in well W-13751 (OFMS 108; Plate 2, cross-section C-C') to 250 feet (76.2 meters) in well W-7104 (OFMS 108; Plate 2, cross-section E-E').

\section{Charlton Member}

The Middle Miocene Charlton Member of the Coosawhatchie Formation (Thcc) consists of moldic dolostones, limestones, clays, and sands. The sediments ranges in color from white and yellowish gray to pale yellowish green. Induration ranges from poor to moderate. Moldic porosity dominates, with occasional intercrystalline porosity in more dolomitic sections. The most common molds observed are from molluscs. Quartz and phosphatic sand are usually present but 
concentrations are characteristically low, often less than ten percent, although they may be higher. Quartz sand is more prevalent than phosphatic sand and ranges in size from fine to coarse. Phosphate content is low, often less than two percent, and the phosphate is typically black to dark brown in color. In some locations, especially near the St. Marys River (north of the mapped area), the Charlton Member is present as a clay phase. The clays are calcareous to dolomitic, poorly to moderately indurated, silty, and are light gray to greenish gray in color (Scott, 1988). The top of the Charlton Member ranges between 10 feet (3.1 meters) above MSL in W-17744/W-18015 (OFMS 108; Plate 2, cross-section C-C') to 68 feet (20.7 meters) below MSL in W-19437 (OFMS 108; Plate 2, cross-sections A-A' and F-F'). The Charlton Member is absent in various wells (OFMS 108; Plate 2), but attains a thickness of 75 feet (22.9 meters) in well W-4197 (OFMS 108; Plate 2, cross-section B-B' and D-D').

\section{Tertiary/Quaternary Systems}

\section{Pliocene/Pleistocene Series}

\section{Cypresshead Formation}

The Pliocene/Pleistocene Cypresshead Formation (TQc), named by Huddlestun (1988), is a mottled reddish-brown to reddish-orange to white, unconsolidated to poorly consolidated, fineto very coarse-grained, variably clayey to clean quartz sand. Cross-beds are common within this formation. Discoid quartzite pebbles, heavy minerals, mica, and ghosts of nearshore marine molluscs are rarely present. The Cypresshead Formation is present in the southwestern portion of the study area along the southern Duval Upland, east of Trail Ridge (OFMS 108, Plates 1 and 3).

Scott, et al., (2001) mapped the entire Duval Upland as Cypresshead Formation. Upon analysis of all available sample sets in the area, the authors of this study do not believe that the sediments in the central portion of the Duval Upland in the study area are Cypresshead Formation and have mapped this area as undifferentiated Quaternary sediments (OFMS 108, Plates 1 and 3). While the occasional set of samples in the area may have some grain-size affinities to the Cypresshead Formation, they generally lack the overall characteristics defining the unit and characteristically have a medium to dark brown clay matrix. The sands in this area tend to be uniformly fine in grain size and low in clay content, often less than ten percent. Mica and heavy minerals are present in a trace amounts.

Elevations of the top of the formation range from approximately 30 feet (9.1 meters) above MSL to around 100 feet (30.5 meters) above MSL in the southwestern corner of the mapped area near Trail Ridge. The Cypresshead Formation thickness ranges up to 60 feet (18.3 meters) in study area wells.

These sediments sit unconformably on the Coosawhatchie Formation (Thc), Charlton Member (Coosawhatchie Formation; Thcc), or undifferentiated Pliocene/Pleistocene shelly sediments (TQsu) in the vicinity of Trail Ridge (OFMS 108; Plates 2 and 3). Permeable sediments of the Cypresshead Formation form part of the surficial aquifer system (SAS; Southeastern Geological Society Ad Hoc Committee on Florida Hydrostratigraphic Unit Definition, 1986). 


\section{Undifferentiated Tertiary/Quaternary Shelly Sediments}

A sequence of undifferentiated Pliocene/Pleistocene shelly sediments lies east of Trail Ridge. Huddlestun (1988) named this unit the Nashua Formation. Much of the evidence listed by Huddlestun (1988) was based on biostratigraphic correlation and not lithologic distinction. As a result of the lithologic variability of the unit, the use of biostratigraphic correlation of Huddleston (1988) and minimal field exposures, these sediments are mapped as undifferentiated Tertiary/Quaternary shelly sediments (TQsu) in this study. While not a formally recognized lithostratigraphic unit, TQsu are mapped following the convention of Scott et al., (2001) in order to facilitate a better understanding of Florida's geology. The unit sits unconformably on the Coosawhatchie Formation of the Hawthorn Group or the Charlton Member of the Coosawhatchie Formation (OFMS 108; Plate 2). Huddlestun (1988) indicated that the unit grades laterally into the Cypresshead Formation (TQc) in the vicinity of the Trail Ridge. Evidence from previous studies (Green et al., 2013a, and Green et al., 2013b), however, indicates that the unit is, at least in part, older than the Cypresshead Formation. This may be a result of prograding of Cypresshead Formation sediments over TQsu marine sediments during changes in sea level. These undifferentiated shelly sands are overlain by the Cypresshead Formation in the Crescent City and DeLand ridges south of the current study area (Green et al., 2013a, and Green et al., 2013b). Elsewhere, the unit is unconformably overlain by undifferentiated Quaternary sediments $(\mathrm{Qu})$, Quaternary beach ridge and dune sediments (Qbd), or Holocene sediments (Qh; OFMS 108, Plate 2). The TQsu sediments are missing in several wells in the study area (OFMS 108, Plate 2), hypothesized to be due to the influence of the St. Johns River and erosion during sea-level fluctuations or dissolution of the carbonates.

Undifferentiated Tertiary/Quaternary shelly sediments (TQsu) consist of fine-to-medium quartz sand with variable amounts of calcilutite, fossil shells, and clay. Fossil shells can be weathered, fragmented, or whole and can be the dominant lithologic component of the unit. Gray clay is a more common matrix material in TQsu in the western portion of the study area, while calcilutite matrix is more common in the eastern portion of the study area, especially near the coast. Clay content ranges from a trace amount up to 15 percent. Other accessory minerals include calcite, aragonite, mica, heavy minerals, and phosphate. Colors range from light gray to light olive gray.

The top of the undifferentiated Tertiary/Quaternary shelly sediments ranges from 24 feet (7.3 meters) above MSL in W-14521, (OFMS 108; Plate 2, cross-section D-D') to 70 feet (21.3 meters) below MSL in W-18283 (OFMS 108; Plate 2, cross-section D-D'). The thickness of the undifferentiated Pliocene/Pleistocene shelly sediments in the cross-section wells varies from 10 feet (3.1 meters) in W-14354 (OFMS 108; Plate 2, cross-sections B-B' and D-D') to 95 feet (28.9 meters) in W-18254 (OFMS 108; Plate 2, cross-section D-D'). Permeable sediments of the undifferentiated Tertiary/Quaternary shelly sediments form part of the surficial aquifer system (SAS; Southeastern Geological Society Ad Hoc Committee on Florida Hydrostratigraphic Unit Definition, 1986).

\section{Pleistocene to Holocene Series}

\section{Undifferentiated Quaternary Sediments}

Undifferentiated Quaternary sediments (Qu) in the study area lie unconformably on the Coosawhatchie Formation of the Hawthorn Group, Charlton Member of the Coosawhatchie 
Formation, undifferentiated Pliocene/Pleistocene shelly sediments or Cypresshead Formation (OFMS 108, Plate 2). While not a formally recognized lithostratigraphic unit, Qu are mapped following the convention of Scott et al. (2001) in order to facilitate a better understanding of Florida's geology. The undifferentiated Quaternary sediments present in the mapped area may be highly variable in thickness. Generally, these undifferentiated Quaternary sediments consist of white to gray to orange to brown, fine- to coarse-grained, clean to clayey unfossiliferous sands, sandy clays and clays with variable admixtures of organics. The undifferentiated Quaternary sediments form part of the surficial aquifer system (SAS; Southeastern Geological Society Ad Hoc Committee on Florida Hydrostratigraphic Unit Definition, 1986).

\section{Quaternary Trail Ridge Sands}

Sediments mapped as Quaternary Trail Ridge Sands (Qtr) include heavy-mineral bearing sediments associated with Trail Ridge, but are not limited to just the ridge itself. While not a formally recognized lithostratigraphic unit, they are mapped following the convention of Scott et al. (2001) in order to facilitate a better understanding of Florida's geology. These sediments consist of unconsolidated to slightly indurated white to tan, medium to fine quartz sands. They contain an average of three percent heavy minerals, of which approximately 45 percent are titanium-rich minerals consisting of ilmenite, luecoxene, and rutile. Other common heavy minerals in the unit include staurolite, zircon, kyanite, sillimanite, corundum, topaz, and tourmaline.

\section{Quaternary Beach Ridge and Dune}

Quaternary beach ridge and dune sediments (Qbd) are a subdivision of the undifferentiated Quaternary sediments that are noted on the basis of surficial expression of relict beach ridges and dunes. While not a formally recognized lithostratigraphic unit, Qbd are mapped following the convention of Scott et al. (2001) in order to facilitate a better understanding of Florida's geology. This unit unconformably overlies undifferentiated Pliocene/Pleistocene shelly sediments (TQsu), or the undifferentiated Quaternary sediments (Qu) in the eastern part of the study area (OFMS 108; Plates 1 and 2).

Beach ridge and dune sediments are dominantly siliciclastic sands and are unconsolidated to poorly consolidated. Organics occur as disseminated organic matrix, roots and plant debris, carbonized remains, or charcoal. The unit is considered part of the surficial aquifer system (SAS; Southeastern Geological Society Ad Hoc Committee on Florida Hydrostratigraphic Unit Definition, 1986).

\section{Holocene Sediments}

Sediments mapped as Holocene (Qh) may include quartz sands, marls, organics, humate, minor carbonate sands, and mud. They may also include fresh-water mollusc shells. Within the study area, they occur as modern barrier islands and floodplain deposits in the vicinity of the St. Johns, Guana, and Tolomato rivers, and along the east coast. These sediments are considered part of the surficial aquifer system (SAS; Southeastern Geological Society Ad Hoc Committee on Florida Hydrostratigraphic Unit Definition, 1986). 


\section{HYDROGEOLOGY}

Hydrostratigraphic units within the map area, in ascending order, consist of the Floridan aquifer system (FAS), the intermediate aquifer system/intermediate confining unit (IAS/ICU), and the surficial aquifer system (SAS; Southeastern Geological Society Ad Hoc Committee on Florida Hydrostratigraphic Unit Definition, 1986). The FAS, the primary source for drinking water in the region, is generally comprised of carbonate units of the Avon Park Formation and the Ocala Limestone. The sands, silts, clays, and carbonates of the Hawthorn Group comprise the IAS/ICU. The IAS/ICU is highly variable in the study area. The SAS is comprised of the Cypresshead Formation, undifferentiated Pliocene/Pleistocene shelly sediments (TQsu), undifferentiated Quaternary sediments $(\mathrm{Qu})$, beach ridge and dune sediments $(\mathrm{Qbd})$, and Holocene sediments $(\mathrm{Qh})$.

\section{GEOPHYSICAL LOGGING}

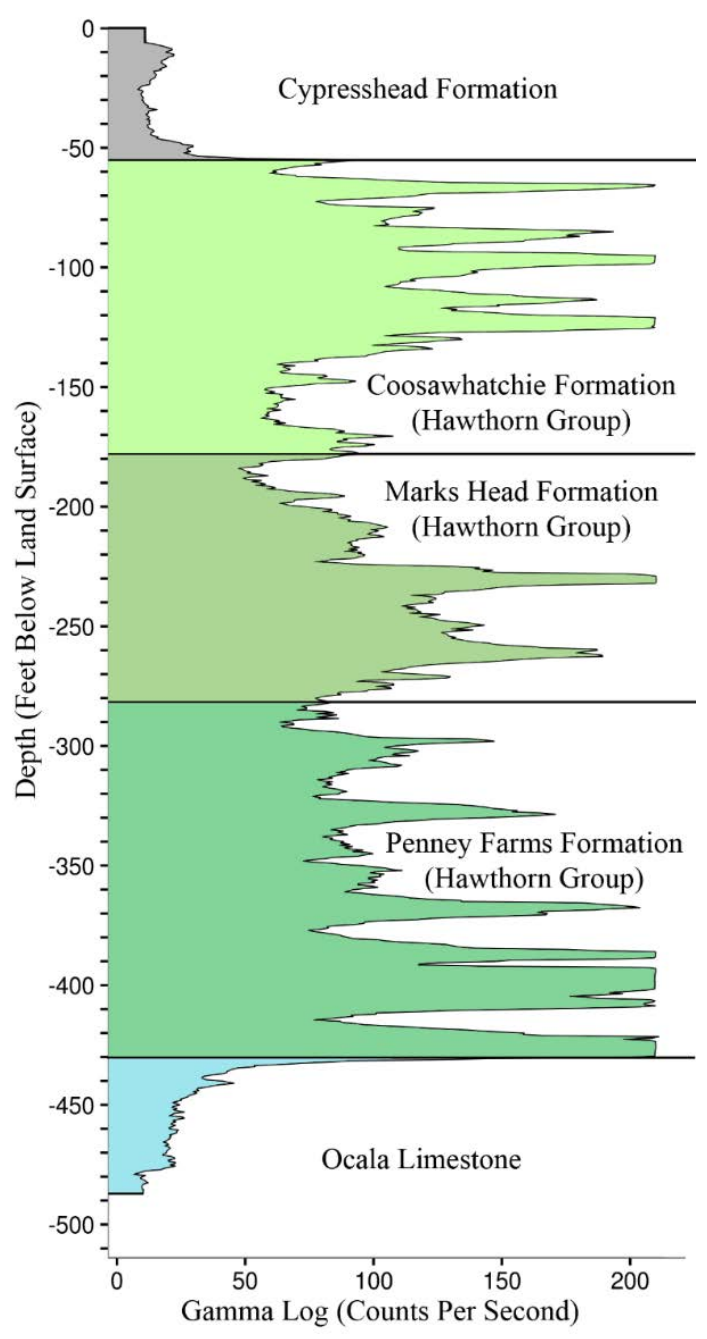

Figure 6. Gamma Log of W-14219 (see OFMS 108, plate 2 , cross section C-C' and D-D').
As part of this project, the Florida Geological Survey (FGS) conducted geophysical logging on new wells drilled in the study area. Boreholes were logged with a variety of geophysical tools, including Gamma (natural gamma log), Caliper, and Resistivity logs. The geophysical log of particular interest in this study was the gamma log for its usefulness in differentiating the various lithostratigraphic units by recording the naturally occurring gamma-ray activity in the lithology of the borehole wall.

By comparing gamma-ray activity between lithostratigraphic units, it is often possible to differentiate them. This $\log$ is particularly useful for differentiating between Hawthorn Group units and subjacent and superjacent formations. Kwader (1982) and Scott (1988) discuss the gamma-ray response from clay minerals and phosphate typical to the formations in the Hawthorn Group. Development of high gamma-ray activity occurs when minerals incorporate high percentages of potassium, uranium, or thorium in their lattice structures. Potassium-rich sources include potassium feldspar, mica, and illitic clay. Uranium and thorium tend to be found in phosphorite, apatite, organic material, and dolomite.

Gamma-ray intensity units are measured in counts per second (CPS). In Figure 6, gamma-ray intensity units are shown on the log horizontal axis in CPS for W-14219 (see OFMS 108, Plate 2, crosssection $\mathrm{C}^{-\mathrm{C}^{\prime}}$ and $\left.\mathrm{D}-\mathrm{D}^{\prime}\right)$. Carbonates of the Ocala Limestone have the lowest intensity gamma-ray peaks, in contrast to the high intensity radioactivity of the Hawthorn Group. Formations above the Hawthorn 
Group, such as the Cypresshead Formation, typically have much lower intensity signatures. In the study area, elevated radioactivity primarily results from the inclusion of phosphate grains. Medium intensity gamma-ray signatures are from moderately radioactive clay minerals and from organic material or peat (Davis et al., 2001).

\section{Stratigraphy and Gamma-Ray Log Interpretation}

Cypresshead Formation

Cypresshead Formation sediments (TQc) unconformably overlie sediments of the Hawthorn Group (OFMS 108, Plate 2) in the southwestern corner of the study area. Cypresshead Formation sediments present in the mapped area may be highly variable in thickness and typically consist of fine to medium quartz sand with variable amounts of clay. The presence of minor phosphate and material reworked from the underlying Hawthorn Group sediments can cause basal spikes in the gamma-ray log, making the base of this unit in such cases problematic to distinguish from the underlying Coosawhatchie Formation (Thc; Hawthorn Group).

Hawthorn Group

The Hawthorn Group consists of a complex sequence of siliciclastics and carbonates with varying percentages of phosphate minerals. The resulting gamma-ray peaks are, in general, significantly higher than those of the formations above and below the Hawthorn Group, which makes this unit easy to discern on geophysical logs (Figure 6).

The Hawthorn Group in the study area consists of, in descending order, the Charlton Member of the Coosawhatchie Formation (Thcc), Coosawhatchie (Thc), Marks Head (Thmh), and Penney Farms (Thpf) formations. According to Scott (1988), the gamma-ray logs for Hawthorn Group in north Florida consist of five generalized zones which may show significant variation in thickness and intensity of peaks within these zones. While it is possible to differentiate formations within the Hawthorn Group using gamma-ray logs, it is best practice to combine the study of geophysical logs along with lithologic inspection in order to break out units within the Hawthorn Group.

The upper, higher-intensity zone and part of the subjacent, lower-intensity zone correlate to the Cooswhatchie Formation (Figure 6). The variable lithologic nature and phosphate content of the Coosawhatchie Formation, particularly in the upper portion of the unit, is readily apparent in the gamma-ray log. This is reflected by the numerous high-intensity peaks and relatively thin beds. The Coosawhatchie Formation in this well consists primarily of siliciclastics with varying amounts of dolomitic clay and fine- to pebble-sized phosphate ranging in content between two and 10 percent.

The Marks Head Formation correlates with part of the low-intensity zone, reflecting the decreased phosphate concentrations, less carbonate, and decrease in clay content. This is followed by the upper part of the high-intensity zone, and the upper part of the second low-intensity zone (Figure 6).

In general, the gamma-ray log of the Penny Farms Formation includes the lower portion of the second low-intensity zone, consisting of sands, clays and dolostones with one to five percent phosphate, followed by a higher intensity gamma-ray intensity zone consisting of clays and dolosilts with low phosphate content. The base of the Penny Farms in this core consists of a thin, 
hard, dolomite with 5 to 10 percent phosphate sand and gravel which is represented on the log by the presence of a higher-intensity spike. Overall, the Penney Farms Formation in this core is highly variable in lithology and phosphate content as reflected in the gamma-ray log. The Penney Farms Formation unconformably overlies the Ocala Limestone. At this contact, the gamma-ray log intensity drops significantly, and the delineation of these two formations is apparent (Figure $6)$.

\section{Ocala Limestone}

In contrast to the higher intensity gamma-ray signature of the Hawthorn Group, the Ocala Limestone is easily identified on the gamma-ray log. This unit characteristically produces the lowest gamma-ray intensity in the Eocene stratigraphic sequence and can be used as a low baseline for relative gamma-ray intensity (Davis et al., 2001).

\section{DERIVATIVE PRODUCTS}

Several derivative products will come from this project. During the mapping project, data from approximately three hundred wells with samples were analyzed. Formation picks, made on all available wells with cores and cuttings samples, allow creation of a structure contour map of the top of the FAS, along with the construction of structure contour and isopach maps of the IAS/ICU in the area. Additional derivative data anticipated to come from this mapping effort include aquifer vulnerability assessment maps. Data derived from prior STATEMAP products have often been used to augment other Florida Geological Survey and Florida aquifer vulnerability assessment (FAVA) projects in the state (Arthur et al., 2007; Baker et al., 2007). 


\section{REFERENCES}

Alt, D., and Brooks, H.K., 1965, Age of the Florida marine terraces: Journal of Geology, v. 73, p. 406-411.

Applin, P., 1951, Possible future petroleum provinces of North America - Florida: American Association of Petroleum Geologists Bulletin, v. 35, p. 405-407.

Applin, P.L., and Applin, E.R., 1944, Regional subsurface stratigraphy and structure of Florida and southern Georgia: American Association of Petroleum Geologists Bulletin, v. 28, p. 16731753.

Arthur, J.D., Wood, H.A.R., Baker, A.E., Cichon, J.R., and Raines, G.L., 2007, Development and implementation of a Bayesian-based aquifer vulnerability assessment in Florida: Natural Resources Research, v. 16, p. 93-107.

Baker, A.E., Wood, H.A.R., and Cichon, J.R., 2007, The Marion County Aquifer Vulnerability Assessment: unpublished report submitted to Marion County Board of County Commissioners in fulfillment of Marion County Project No. SS06-01, March 2007, 42 p.

Clark, W.Z., and Zisa, A. C., 1976, Physiographic map of Georgia: Geologic Survey Branch of the Environmental Protection Division of the Georgia Department of Natural Resources, scale $1: 2,000,000$.

Colquhoun, D.J., Johnson, G.H., Peebles, P.C., Huddlestun, P.F., and Scott, T., 1991, Quaternary geology of the Atlantic Coastal Plain, in Morrison, R.B., ed., Quaternary nonglacial geology; Conterminous U.S.: Boulder, Geological Society of America, The Geology of North America, v. K-2, p. 629-650.

Cooke, C.W., 1931, Seven coastal terraces in the southeastern United States: Washington Academy of Sciences Journal, v. 21, p. 503-513.

, 1939, Scenery of Florida interpreted by a geologist: Florida Geological Survey Bulletin 17, 120 p.

Copeland, R., Doran, N.A., White, A.J., and Upchurch, S.B., 2009, Regional and statewide trends in Florida's spring and well groundwater quality (1991-2003): Florida Geological Survey Bulletin 69, 203 p.

Dall, W.H., and Harris, G.D., 1892, Correlation papers, Neocene: U.S. Geological Survey Bulletin 84, 349 p.

Davis, J., Johnson R.A., Boniol D. and Rupert, F., 2001, Guidebook to the correlation of geophysical well logs within the St. Johns River Water Management District: Florida Geological Survey Special Publication 50, 114 p. 
Goodell, H.G., and Yon, J.W., Jr., 1960, The regional lithostratigraphy of the post-Eocene rocks of Florida: Southeastern Geological Society, $9^{\text {th }}$ Field Trip Guidebook, p. 75-113.

Green, R.C., Evans, W.L., III, Paul , D.T., and Scott, T.M., 2005, Geologic map of the eastern portion of the USGS Gainesville 30 × 60 minute quadrangle, northern Florida: Florida Geological Survey Open-File Map Series 94, scale 1:100,000, 2 plates.

Green, R C., Evans, W.L. III, Bassett, S.W., and Hannon, L.M., 2013a, Geologic map of the USGS Daytona Beach 30 x 60 minute quadrangle, northeast Florida: Florida Geological Survey Open-File Map Series 105, scale 1:100,000, 3 plates.

Green, R.C., Evans, W.L. III, Bassett, S.W., and Hannon, L.M., 2013b, Text to accompany geologic map of the USGS Daytona Beach 30 x 60 minute quadrangle northeast Florida: Florida Geological Survey Open-File Report 101, 37p.

Green, R.C., Williams, C.P., Campbell, K.M., Bambach, P.W., Hannon, L. M., Bassett, S.W., Evans, W.L., Paul, D.T., and Apolinar, B., 2014a, Geologic map of the USGS St. Augustine 30 x 60 minute quadrangle, northeast Florida: Florida Geological Survey Open-File Map Series 106, scale 1:100,000, 3 plates.

Green, R.C., Williams, C.P., Campbell, K.M., Bambach, P.W., Hannon, L. M., Bassett, S.W., Evans, W.L., Paul, D.T., and Apolinar, B., 2014b, Geologic map of the USGS St. Augustine 30 x 60 minute quadrangle, northeast Florida: Florida Geological Survey Open-File Report 102, 34p.

Green, R.C., Williams, C.P., Bambach, P.W., Hannon, L.M., Apolinar, B., Campbell, K.M., and Dyer, S.B., 2015a, Geologic map of the USGS Orlando 30 x 60 minute quadrangle, central Florida: Florida Geological Survey Open File Map Series 107, scale 1:100,000.

Green, R.C., Williams, C.P., Bambach, P.W., Hannon, L.M., Apolinar, B., Campbell, K.M., and Dyer, S.B., 2015b, Text to accompany geologic map of the USGS Orlando 30 x 60 minute quadrangle, central Florida: Florida Geological Survey Open File Report 104, 37 p.

Huddlestun, P.F., 1988, A revision of the lithostratigraphic units of the Coastal Plain of Georgia, the Miocene through Holocene: Georgia Geologic Survey Bulletin 104, 262 p.

Kwader T., 1982, Interpretation of borehole geophysical logs in shallow carbonate environments and their application to ground water resources investigations [Ph.D. Thesis]: Florida State University, Tallahassee, $322 \mathrm{p}$.

Leve, G.W., 1965, Groundwater in Duval and Nassau Counties, Florida: Florida Geological Survey, Report of Investigation 43, 91 p.

MacNeil, F.S., 1950, Pleistocene shorelines in Florida and Georgia: U.S. Geological Survey Professional Paper 221-F, p. 95-107. 


\section{FLORIDA GEOLOGICAL SURVEY}

Matson, G.C., and Sanford, S., 1913, Geology and groundwater of Florida: U.S. Geological Survey Water Supply Paper 319, 445 p.

Miller, J.A., 1986, Hydrogeologic framework of the Floridan aquifer system in Florida and in parts of Georgia, Alabama, and South Carolina: Regional Aquifer-System Analysis: U.S. Geological Survey Professional Paper 1403-B, 91 p., 33 plates.

Puri, H.S., and Vernon, R.O., 1964, Summary of the geology of Florida and a guidebook to the classic exposures: Florida Geological Survey Special Publication 5, revised, 312 p.

Riggs, S.R., 1979a, Petrology of the Tertiary phosphorite system of Florida: Economic Geology, V. 74, p. 195-220.

, 1979b, Phosphorite sedimentation in Florida - a model phosphogenic system: Economic Geology, v. 74, p. 285-314.

Schmidt, W., 1984, Neogene stratigraphy and geologic history of the Apalachicola Embayment: Florida Geological Survey Bulletin 58, 146 p.

Scott, T.M., 1983, The Hawthorn Formation of Northeastern Florida - Part I: The geology of the Hawthorn Formation of Northeastern Florida: Florida Geological Survey Report of Investigation 94, $90 \mathrm{p}$.

, 1988, The lithostratigraphy of the Hawthorn Group (Miocene) of Florida: Florida Geological Survey Bulletin 59, 148 p.

, 1991, A geological overview, in Scott, T.M., Lloyd, J.M., and Maddox, G.L., eds., Florida's ground-water quality monitoring program, hydrogeologic framework: Florida Geological Survey Special Publication 32, 97 p.

, 1992a, Geologic map of Clay County, Florida: Florida Geological Survey Open-File Map Series 5, scale 1:126,720.

, 1992b, Geologic map of Duval County, Florida: Florida Geological Survey Open-File Map Series 4, scale 1:126,720.

, 1992c, Geologic map of Nassau County, Florida: Florida Geological Survey OpenFile Map Series 3, scale 1:126,720.

, 1992d, Geologic map of St. Johns County, Florida: Florida Geological Survey OpenFile Map Series 68, scale 1:126,720.

, 1997, Miocene to Holocene history of Florida, in Randazzo, A.F. and Jones, D.S., eds., The geology of Florida: Gainesville, University Press of Florida, p. 57-67.

, 2001, Text to accompany the geologic map of Florida: Florida Geological Survey Open-File Report 80, 29 p. 
Scott, T.M., Campbell, K.M., Rupert, F.R., Arthur, J.A., Green, R.C., Means, G.H., Missimer, T.M., Lloyd, J.M., and Duncan, J.G., 2001, Geologic map of Florida: Florida Geological Survey Map Series 146, scale 1:750,000.

Scott, T.M., Means, G.H., Means, R.C., and Meegan R.P., 2002, First magnitude springs of Florida: Florida Geological Survey Open-File Report 85, 138 p.

Scott, T.M., Means, G.H., Meegan, R.P., Means, R.C., Upchurch, S.B., Copeland, R.E., Jones, J., Roberts, T., and Willet, A., 2004, Springs of Florida: Florida Geological Survey Bulletin 66, $377 \mathrm{p}$.

Southeastern Geological Society Ad Hoc Committee on Florida Hydrostratigraphic Unit Definition, 1986, Hydrogeological units of Florida: Florida Geological Survey Special Publication 28, 8 p.

Upchurch, S.B., Champion, K.M., Schneider, J.C., Hornsby, D., Ceryak, R., and Zwanka, W., 2004, Defining springshed boundaries and water-quality domains near first-magnitude springs in north Florida [abstract]: Florida Scientist, v. 67, Supplement 1, p. 52

Vernon, R.O., 1951a, Surface occurrences of geologic formations in Florida (geologic map): Florida Geological Survey Map Series 3, 1 sheet, scale approximately 48 miles to 1 inch.

White, W.A., 1970, The geomorphology of the Florida peninsula: Florida Geological Survey Bulletin 51, 164 p.

Williams, K.E. Dodd, K., and Randazzo, A.F., 1977, The geology of the western part of Alachua County, Florida: Florida Geological Survey Report of Investigations 85, 98 p.

Williams, C.P., Cichon, J.R., Hartman, L.M., and Apolinar, B., 2016 (in review), Geomorphology and geology of selected coastal regions in northeastern Florida: Florida Geological Survey.

Williams, C.P., Scott, T.M., Paul, D.T., and Means, G.H., (in preparation), Geomorphic map of Florida: Florida Geological Survey, scale 1:750,000. 


\section{ACKNOWLEDGEMENTS}

The authors extend many thanks to the personnel that assisted with access to land holdings: Frank Burley and Conrad Wysocki, Florida Department of Agricultural and Consumer Services helped with access to drilling in Carey State Forest. Justin Ellenberger from the Florida Fish and Wildlife Conservation Commission, helped with access to Guana River Wildlife Management Area for drilling and sampling. Robin Mantz and Tony Williams, City of Jacksonville, assisted with drilling access for the Panther Road site.

Brianne Apolinar, Phil Bambach, Ken Campbell, Bob Cleveland, Matt Pritchett, Guy Richardson, and Eric Thomas provided field support for drilling operations. Dan Phelps, David Paul, and Levi Hannon assisted in logging of boreholes. Levi Hannon, Alan Baker, Seth Bassett, Katherine White, and James Cichon worked to make sure all wells were appropriately located using every piece of archived well location information that could be found. Scott Barrett Dyer processed field samples. Thank you to Clint Kromhout, Alan Baker, and Harley Means who reviewed, discussed and edited the product. Tom Scott continues to be an asset to geologic mapping in Florida and the ongoing work to revise the state's geomorphic map. This geologic map was funded in part by the Office of the Florida Geological Survey of the Florida Department of Environmental Protection and by the United States Geological Survey National Cooperative Geologic Mapping Program under assistance award number G15AC00309 in Federal fiscal year 2015. 


\section{APPENDIX A: FGS WELLS UTILIZED FOR STUDY}

This table lists FGS wells within the boundaries of the USGS Jacksonville $30 \times 60$ minute quadrangle utilized for the top of rock model and/or geologic mapping. Due to graphical constraints, not all wells will appear on Plate 1 of OFMS 108. The first 40 wells in the table were utilized for geologic cross-sections and appear on Plates 1 and 2 of OFMS 108.

\begin{tabular}{|c|c|c|c|c|c|c|c|}
\hline $\begin{array}{l}\text { Map } \\
\text { ID }\end{array}$ & $\begin{array}{c}\text { Well } \\
\text { Label }\end{array}$ & $\begin{array}{l}\text { Sample } \\
\text { Type }\end{array}$ & Latitude & Longitude & 24K Quad & $\begin{array}{l}\text { Elevation } \\
\text { (ft.) }\end{array}$ & $\begin{array}{l}\text { Total } \\
\text { Depth } \\
\text { (ft.) }\end{array}$ \\
\hline 1 & W-1045 & Cuttings & 30.41932 & -81.80168 & DINSMORE & 19 & 75 \\
\hline 2 & W-2208 & Cuttings & 30.14971 & -81.38403 & PALM VALLEY & 7 & 410 \\
\hline 3 & $\mathrm{~W}-2280$ & Cuttings & 30.28219 & -81.72343 & JACKSONVILLE & 11 & 1250 \\
\hline 4 & W-3416 & Cuttings & 30.29610 & -81.59051 & ARLINGTON & 9 & 1000 \\
\hline 5 & W-3509 & Cuttings & 30.29691 & -81.64259 & JACKSONVILLE & 22 & 1500 \\
\hline 6 & W-3567 & Cuttings & 30.42389 & -81.64861 & TROUT RIVER & 24 & 740 \\
\hline 7 & W-3788 & Cuttings & 30.42785 & -81.60282 & EASTPORT & 10 & 1012 \\
\hline 8 & W-3990 & Cuttings & 30.23552 & -81.89871 & FIFTONE & 75 & 964 \\
\hline 9 & W-4197 & Cuttings & 30.26750 & -81.90730 & BALDWIN & 83 & 1300 \\
\hline 10 & W-4883 & Cuttings & 30.40940 & -81.72239 & TROUT RIVER & 13 & 1225 \\
\hline 11 & W-5882 & Cuttings & 30.39107 & -81.41453 & MAYPORT & 7 & 814 \\
\hline 12 & W-6542 & Cuttings & 30.31643 & -81.39858 & JACKSONVILLE BEACH & 7 & 1201 \\
\hline 13 & W-7104 & Cuttings & 30.35494 & -81.60450 & ARLINGTON & 44 & 1300 \\
\hline 14 & W-8736 & Cuttings & 30.40468 & -81.87372 & DINSMORE & 85 & 708 \\
\hline 15 & W-10773 & Cuttings & 30.36396 & -81.42082 & JACKSONVILLE BEACH & 5 & 705 \\
\hline 16 & W-11273 & Cuttings & 30.30393 & -81.43830 & JACKSONVILLE BEACH & 6 & 616 \\
\hline 17 & W-11777 & Cuttings & 30.18472 & -81.37778 & PALM VALLEY & 7 & 1014 \\
\hline 18 & W-12224 & Cuttings & 30.28638 & -81.80419 & MARIETTA & 76 & 761 \\
\hline 19 & W-12859 & Cuttings & 30.28496 & -81.97344 & BALDWIN & 84 & 905 \\
\hline 20 & W-13751 & Core & 30.08499 & -81.45837 & DURBIN & 63 & 342 \\
\hline 21 & W-14219 & Core & 30.11528 & -81.88250 & MIDDLEBURG SW & 89 & 492 \\
\hline 22 & W-15217 & Cuttings & 30.26705 & -81.39625 & JACKSONVILLE BEACH & 18 & 890 \\
\hline 23 & W-16250 & Cuttings & 30.09500 & -81.61433 & ORANGEDALE & 11 & 500 \\
\hline 24 & W-16381 & Cuttings & 30.09524 & -81.76527 & MIDDLEBURG & 12 & 651 \\
\hline 25 & W-16535 & Cuttings & 30.03555 & -81.65361 & FLEMING ISLAND & 6 & 961 \\
\hline 26 & W-16559 & Cuttings & 30.22750 & -81.58444 & BAYARD & 21 & 860 \\
\hline 27 & W-16564 & Cuttings & 30.29542 & -81.50942 & ARLINGTON & 38 & 1090 \\
\hline 28 & W-16679 & Cuttings & 30.45730 & -81.90913 & BRYCEVILLE & 69 & 90 \\
\hline 29 & W-16825 & Cuttings & 30.04253 & -81.89531 & MIDDLEBURG SW & 76 & 441 \\
\hline 30 & W-17544 & Cuttings & 30.40250 & -81.92111 & BRYCEVILLE & 78 & 500 \\
\hline 31 & W-17774 & Cuttings & 30.15721 & -81.93774 & FIFTONE & 79 & 82 \\
\hline 32 & W-17778 & Cuttings & 30.15750 & -81.57528 & BAYARD & 25 & 420 \\
\hline 33 & W-18015 & Cuttings & 30.15722 & -81.93777 & FIFTONE & 79 & 540 \\
\hline 34 & W-18418 & Core & 30.02283 & -81.32763 & SOUTH PONTE VEDRA BEACH & 2 & 320 \\
\hline 35 & W-18529 & Cuttings & 30.08389 & -81.72305 & FLEMING ISLAND & 11 & 290 \\
\hline 36 & W-19437 & Core & 30.44498 & -81.41803 & MAYPORT & 17 & 435 \\
\hline 37 & W-19462 & Core & 30.45192 & -81.46951 & MAYPORT & 11 & 160 \\
\hline 38 & W-19561 & Core & 30.16700 & -81.88261 & FIFTONE & 79 & 325 \\
\hline
\end{tabular}


FLORIDA GEOLOGICAL SURVEY

\begin{tabular}{|c|c|c|c|c|c|c|c|}
\hline $\begin{array}{l}\text { Map } \\
\text { ID }\end{array}$ & $\begin{array}{l}\text { Well } \\
\text { Label }\end{array}$ & $\begin{array}{l}\text { Sample } \\
\text { Type }\end{array}$ & Latitude & Longitude & 24K Quad & $\begin{array}{l}\text { Elevation } \\
\text { (ft.) }\end{array}$ & $\begin{array}{l}\text { Total } \\
\text { Depth } \\
\text { (ft.) }\end{array}$ \\
\hline 39 & W-19570 & Core & 30.08592 & -81.34956 & SOUTH PONTE VEDRA BEACH & 11 & 325 \\
\hline 40 & W-19587 & Core & 30.33033 & -81.90794 & BALDWIN & 85 & 339.5 \\
\hline 41 & W-27 & Cuttings & 30.24096 & -81.68734 & ORANGE PARK & 15 & 669 \\
\hline 42 & $\mathrm{~W}-28$ & Cuttings & 30.31191 & -81.70538 & JACKSONVILLE & 24 & 547 \\
\hline 43 & W-48 & Cuttings & 30.33625 & -81.65478 & JACKSONVILLE & 12 & 981 \\
\hline 44 & W-73 & Cuttings & 30.33195 & -81.72150 & JACKSONVILLE & 24 & 600 \\
\hline 45 & $\mathrm{~W}-78$ & Cuttings & 30.16580 & -81.70204 & ORANGE PARK & 21 & 370 \\
\hline 46 & W-116 & Cuttings & 30.33072 & -81.78815 & MARIETTA & 59 & 1060 \\
\hline 47 & W-157 & Cuttings & 30.31246 & -81.70954 & JACKSONVILLE & 18 & 1260 \\
\hline 48 & W-303 & Cuttings & 30.33968 & -81.65759 & JACKSONVILLE & 12 & 1244 \\
\hline 49 & W-304 & Cuttings & 30.34080 & -81.65926 & JACKSONVILLE & 16 & 1249 \\
\hline 50 & W-306 & Cuttings & 30.31107 & -81.65649 & JACKSONVILLE & 9 & 1307 \\
\hline 51 & W-322 & Cuttings & 30.30191 & -81.64704 & JACKSONVILLE & 17 & 1278 \\
\hline 52 & W-392 & Cuttings & 30.31517 & -81.39927 & JACKSONVILLE BEACH & 8 & 622 \\
\hline 53 & W-513 & Cuttings & 30.22080 & -81.67398 & ORANGE PARK & 11 & 1005 \\
\hline 54 & W-514 & Cuttings & 30.21901 & -81.68517 & ORANGE PARK & 9 & 1015 \\
\hline 55 & W-521 & Cuttings & 30.26560 & -81.63015 & JACKSONVILLE & 25 & 610 \\
\hline 56 & W-523 & Cuttings & 30.33118 & -81.60344 & ARLINGTON & 24 & 748 \\
\hline 57 & W-544 & Cuttings & 30.41884 & -81.64703 & TROUT RIVER & 19 & 1019 \\
\hline 58 & W-581 & Cuttings & 30.22802 & -81.88594 & FIFTONE & 78 & 990 \\
\hline 59 & W-599 & Cuttings & 30.30302 & -81.66232 & JACKSONVILLE & 4 & 700 \\
\hline 60 & W-659 & Cuttings & 30.29052 & -81.97900 & BALDWIN & 86 & 750 \\
\hline 61 & W-661 & Cuttings & 30.22996 & -81.70482 & ORANGE PARK & 6 & 987 \\
\hline 62 & W-731 & Cuttings & 30.24885 & -81.89844 & FIFTONE & 79 & 780 \\
\hline 63 & W-741 & Cuttings & 30.32880 & -81.55817 & ARLINGTON & 50 & 1050 \\
\hline 64 & W-743 & Cuttings & 30.05774 & -81.64009 & FLEMING ISLAND & 29 & 300 \\
\hline 65 & W-826 & Cuttings & 30.30051 & -81.64510 & JACKSONVILLE & 22 & 1064 \\
\hline 66 & W-827 & Cuttings & 30.35971 & -81.68660 & JACKSONVILLE & 25 & 1073 \\
\hline 67 & W-830 & Cuttings & 30.35603 & -81.68658 & JACKSONVILLE & 26 & 1356 \\
\hline 68 & W-831 & Cuttings & 30.35577 & -81.68955 & JACKSONVILLE & 20 & 1053 \\
\hline 69 & W-897 & Cuttings & 30.38857 & -81.41093 & MAYPORT & 8 & 764 \\
\hline 70 & W-900 & Cuttings & 30.15985 & -81.65224 & ORANGE PARK & 13 & 633 \\
\hline 71 & W-1043 & Cuttings & 30.41547 & -81.69361 & TROUT RIVER & 15 & 46 \\
\hline 72 & W-1045 & Cuttings & 30.41932 & -81.80168 & DINSMORE & 19 & 75 \\
\hline 73 & W-1046 & Cuttings & 30.40393 & -81.89101 & BRYCEVILLE & 79 & 106 \\
\hline 74 & W-1071 & Cuttings & 30.03685 & -81.88472 & MIDDLEBURG SW & 22 & 136 \\
\hline 75 & W-1075 & Cuttings & 30.10096 & -81.76827 & MIDDLEBURG & 8 & 55 \\
\hline 76 & W-1076 & Cuttings & 30.07379 & -81.86005 & MIDDLEBURG & 24 & 65 \\
\hline 77 & W-1077 & Cuttings & 30.03724 & -81.88513 & MIDDLEBURG SW & 23 & 60 \\
\hline 78 & W-1078 & Cuttings & 30.06631 & -81.97896 & MIDDLEBURG SW & 79 & 80 \\
\hline 79 & W-1590 & Core & 30.09047 & -81.80779 & MIDDLEBURG & 20 & 5862 \\
\hline 80 & W-2182 & Cuttings & 30.35878 & -81.69053 & JACKSONVILLE & 17 & 1322 \\
\hline 81 & W-2207 & Cuttings & 30.29325 & -81.50981 & ARLINGTON & 36 & 1105 \\
\hline 82 & W-2276 & Cuttings & 30.24444 & -81.72317 & ORANGE PARK & 18 & 775 \\
\hline
\end{tabular}


OPEN-FILE REPORT 105

\begin{tabular}{|c|c|c|c|c|c|c|c|}
\hline $\begin{array}{l}\text { Map } \\
\text { ID }\end{array}$ & $\begin{array}{l}\text { Well } \\
\text { Label }\end{array}$ & $\begin{array}{l}\text { Sample } \\
\text { Type }\end{array}$ & Latitude & Longitude & 24K Quad & $\begin{array}{l}\text { Elevation } \\
\text { (ft.) }\end{array}$ & $\begin{array}{l}\text { Total } \\
\text { Depth } \\
\text { (ft.) }\end{array}$ \\
\hline 83 & W-2443 & Cuttings & 30.28691 & -81.56872 & ARLINGTON & 5 & 750 \\
\hline 84 & W-2558 & Cuttings & 30.39591 & -81.63594 & TROUT RIVER & 16 & 1015 \\
\hline 85 & W-2803 & Cuttings & 30.30256 & -81.97444 & BALDWIN & 85 & 716 \\
\hline 86 & W-2888 & Cuttings & 30.24274 & -81.73371 & ORANGE PARK & 4 & 672 \\
\hline 87 & W-2953 & Cuttings & 30.28014 & -81.64722 & JACKSONVILLE & 19 & 750 \\
\hline 88 & W-2960 & Cuttings & 30.22941 & -81.88594 & FIFTONE & 76 & 950 \\
\hline 89 & W-3013 & Cuttings & 30.23444 & -81.69530 & ORANGE PARK & 13 & 460 \\
\hline 90 & W-3074 & Cuttings & 30.31418 & -81.64844 & JACKSONVILLE & 0 & 760 \\
\hline 91 & W-3120 & Cuttings & 30.42167 & -81.60083 & EASTPORT & 14 & 1006 \\
\hline 92 & W-3282 & Cuttings & 30.28451 & -81.59187 & ARLINGTON & 22 & 1006 \\
\hline 93 & W-3344 & Cuttings & 30.31667 & -81.65667 & JACKSONVILLE & 10 & 760 \\
\hline 94 & W-3345 & Cuttings & 30.44000 & -81.75445 & DINSMORE & 18 & 750 \\
\hline 95 & W-3361 & Cuttings & 30.47829 & -81.62566 & TROUT RIVER & 31 & 1000 \\
\hline 96 & W-3435 & Cuttings & 30.24686 & -81.60828 & BAYARD & 17 & 1150 \\
\hline 97 & W-3464 & Cuttings & 30.16607 & -81.62759 & ORANGE PARK & 18 & 940 \\
\hline 98 & W-3492 & Cuttings & 30.40389 & -81.69556 & TROUT RIVER & 12 & 0 \\
\hline 99 & W-3542 & Cuttings & 30.24289 & -81.77439 & JACKSONVILLE HEIGHTS & 87 & 1204 \\
\hline 100 & W-3591 & Cuttings & 30.16137 & -81.60077 & BAYARD & 21 & 528 \\
\hline 101 & W-3674 & Cuttings & 30.28774 & -81.39503 & JACKSONVILLE BEACH & 10 & 800 \\
\hline 102 & W-3718 & Cuttings & 30.32638 & -81.40107 & JACKSONVILLE BEACH & 8 & 1008 \\
\hline 103 & W-3786 & Cuttings & 30.31302 & -81.71899 & JACKSONVILLE & 22 & 705 \\
\hline 104 & W-3961 & Cuttings & 30.03774 & -81.89668 & MIDDLEBURG SW & 79 & 359 \\
\hline 105 & W-4012 & Cuttings & 30.40107 & -81.64482 & TROUT RIVER & 6 & 1009 \\
\hline 106 & W-4202 & Cuttings & 30.30083 & -81.97267 & BALDWIN & 85 & 715 \\
\hline 107 & W-4210 & Cuttings & 30.19935 & -81.62862 & ORANGE PARK & 19 & 720 \\
\hline 108 & W-4695 & Cuttings & 30.20500 & -81.69389 & ORANGE PARK & 27 & 522 \\
\hline 109 & W-4913 & Cuttings & 30.37504 & -81.58614 & EASTPORT & 22 & 1045 \\
\hline 110 & W-5298 & Cuttings & 30.24639 & -81.76986 & JACKSONVILLE HEIGHTS & 77 & 1149 \\
\hline 111 & W-5311 & Cuttings & 30.37875 & -81.72514 & TROUT RIVER & 6 & 920 \\
\hline 112 & W-5322 & Cuttings & 30.33218 & -81.56037 & ARLINGTON & 26 & 1012 \\
\hline 113 & W-5323 & Cuttings & 30.24718 & -81.62287 & BAYARD & 20 & 1170 \\
\hline 114 & W-5374 & Cuttings & 30.29786 & -81.77389 & MARIETTA & 17 & 704 \\
\hline 115 & W-5459 & Cuttings & 30.33552 & -81.59621 & ARLINGTON & 44 & 1411 \\
\hline 116 & W-5460 & Cuttings & 30.35192 & -81.56901 & ARLINGTON & 43 & 1301 \\
\hline 117 & W-5521 & Cuttings & 30.33815 & -81.52351 & ARLINGTON & 43 & 752 \\
\hline 118 & W-5632 & Cuttings & 30.29941 & -81.77483 & MARIETTA & 24 & 1000 \\
\hline 119 & W-5749 & Cuttings & 30.20756 & -81.58157 & BAYARD & 26 & 670 \\
\hline 120 & W-6254 & Cuttings & 30.37441 & -81.73040 & JACKSONVILLE & 10 & 1326 \\
\hline 121 & W-6301 & Cuttings & 30.28659 & -81.79077 & MARIETTA & 80 & 1043 \\
\hline 122 & W-6465 & Cuttings & 30.39360 & -81.55847 & EASTPORT & 15 & 801 \\
\hline 123 & W-7508 & Cuttings & 30.03782 & -81.87611 & MIDDLEBURG SW & 9 & 107 \\
\hline 124 & W-7509 & Cuttings & 30.08844 & -81.86878 & MIDDLEBURG & 21 & 107 \\
\hline 125 & W-7510 & Cuttings & 30.07470 & -81.85179 & MIDDLEBURG & 4 & 100 \\
\hline 126 & W-7514 & Cuttings & 30.07028 & -81.52750 & ORANGEDALE & 32 & 100 \\
\hline
\end{tabular}


FLORIDA GEOLOGICAL SURVEY

\begin{tabular}{|c|c|c|c|c|c|c|c|}
\hline $\begin{array}{l}\text { Map } \\
\text { ID }\end{array}$ & $\begin{array}{l}\text { Well } \\
\text { Label }\end{array}$ & $\begin{array}{l}\text { Sample } \\
\text { Type }\end{array}$ & Latitude & Longitude & 24K Quad & $\begin{array}{l}\text { Elevation } \\
\text { (ft.) }\end{array}$ & $\begin{array}{l}\text { Total } \\
\text { Depth } \\
\text { (ft.) }\end{array}$ \\
\hline 127 & W-7517 & Cuttings & 30.08860 & -81.83488 & MIDDLEBURG & 27 & 102 \\
\hline 128 & W-7996 & Cuttings & 30.30496 & -81.63010 & JACKSONVILLE & 18 & 2486 \\
\hline 129 & W-8207 & Cuttings & 30.16421 & -81.74185 & ORANGE PARK & 65 & 125 \\
\hline 130 & W-8306 & Cuttings & 30.48691 & -81.67844 & TROUT RIVER & 22 & 1098 \\
\hline 131 & W-8371 & Cuttings & 30.48693 & -81.67847 & TROUT RIVER & 21 & 1098 \\
\hline 132 & W-10359 & Cuttings & 30.38552 & -81.49371 & MAYPORT & 14 & 700 \\
\hline 133 & $\mathrm{~W}-10630$ & Cuttings & 30.14285 & -81.74613 & ORANGE PARK & 31 & 864 \\
\hline 134 & W-10633 & Cuttings & 30.17812 & -81.71316 & ORANGE PARK & 11 & 616 \\
\hline 135 & W-10634 & Cuttings & 30.48846 & -81.63368 & TROUT RIVER & 29 & 815 \\
\hline 136 & W-10635 & Cuttings & 30.36608 & -81.58038 & ARLINGTON & 16 & 1104 \\
\hline 137 & W-10636 & Cuttings & 30.48632 & -81.70427 & TROUT RIVER & 24 & 1105 \\
\hline 138 & W-10919 & Cuttings & 30.21417 & -81.61667 & BAYARD & 6 & 740 \\
\hline 139 & W-10920 & Cuttings & 30.45885 & -81.63815 & TROUT RIVER & 29 & 1330 \\
\hline 140 & W-10921 & Cuttings & 30.35913 & -81.47376 & JACKSONVILLE BEACH & 25 & 704 \\
\hline 141 & W-11281 & Cuttings & 30.11583 & -81.60278 & ORANGEDALE & 14 & 600 \\
\hline 142 & W-11548 & Cuttings & 30.42449 & -81.66037 & TROUT RIVER & 23 & 1296 \\
\hline 143 & W-11581 & Cuttings & 30.20302 & -81.71454 & ORANGE PARK & 18 & 850 \\
\hline 144 & W-11582 & Cuttings & 30.20793 & -81.73676 & ORANGE PARK & 12 & 950 \\
\hline 145 & W-11584 & Cuttings & 30.14281 & -81.74641 & ORANGE PARK & 32 & 864 \\
\hline 146 & W-11585 & Cuttings & 30.04841 & -81.82793 & MIDDLEBURG & 75 & 616 \\
\hline 147 & W-11778 & Cuttings & 30.36052 & -81.41148 & JACKSONVILLE BEACH & 7 & 618 \\
\hline 148 & W-12056 & Cuttings & 30.17790 & -81.73869 & ORANGE PARK & 57 & 1014 \\
\hline 149 & W-12223 & Cuttings & 30.28638 & -81.80419 & MARIETTA & 76 & 762 \\
\hline 150 & W-12278 & Cuttings & 30.19941 & -81.62844 & ORANGE PARK & 24 & 1000 \\
\hline 151 & W-12383 & Cuttings & 30.38080 & -81.60807 & EASTPORT & 11 & 1009 \\
\hline 152 & W-12532 & Cuttings & 30.24014 & -81.76884 & JACKSONVILLE HEIGHTS & 78 & 1130 \\
\hline 153 & W-12782 & Cuttings & 30.30552 & -81.64982 & JACKSONVILLE & 12 & 1296 \\
\hline 154 & W-12847 & Cuttings & 30.33515 & -81.59203 & ARLINGTON & 46 & 1360 \\
\hline 155 & W-13189 & Cuttings & 30.17758 & -81.73839 & ORANGE PARK & 56 & 1002 \\
\hline 156 & W-13343 & Cuttings & 30.41473 & -81.61009 & EASTPORT & 17 & 660 \\
\hline 157 & W-13411 & Cuttings & 30.31274 & -81.78094 & MARIETTA & 60 & 681 \\
\hline 158 & W-13492 & Cuttings & 30.45361 & -81.61833 & EASTPORT & 11 & 1280 \\
\hline 159 & W-13562 & Cuttings & 30.14256 & -81.74622 & ORANGE PARK & 29 & 861 \\
\hline 160 & W-14193 & Core & 30.15167 & -81.76028 & JACKSONVILLE HEIGHTS & 44 & 357 \\
\hline 161 & W-14278 & Cuttings & 30.38412 & -81.41147 & MAYPORT & 9 & 1000 \\
\hline 162 & W-14300 & Cuttings & 30.22135 & -81.67621 & ORANGE PARK & 10 & 1000 \\
\hline 163 & W-14311 & Cuttings & 30.38495 & -81.40926 & MAYPORT & 5 & 1000 \\
\hline 164 & W-14619 & Core & 30.39250 & -81.56306 & EASTPORT & 9 & 510 \\
\hline 165 & W-14731 & Cuttings & 30.38385 & -81.49703 & MAYPORT & 15 & 204 \\
\hline 166 & W-14733 & Cuttings & 30.00897 & -81.42562 & DURBIN & 31 & 74 \\
\hline 167 & W-14734 & Cuttings & 30.43991 & -81.41491 & MAYPORT & 9 & 94 \\
\hline 168 & W-15214 & Cuttings & 30.27068 & -81.39514 & JACKSONVILLE BEACH & 16 & 906 \\
\hline 169 & W-16169 & Cuttings & 30.28294 & -81.98455 & BALDWIN & 85 & 100 \\
\hline 170 & W-16209 & Cuttings & 30.00896 & -81.69977 & FLEMING ISLAND & 16 & 1000 \\
\hline
\end{tabular}


OPEN-FILE REPORT 105

\begin{tabular}{|c|c|c|c|c|c|c|c|}
\hline $\begin{array}{c}\text { Map } \\
\text { ID }\end{array}$ & $\begin{array}{c}\text { Well } \\
\text { Label }\end{array}$ & $\begin{array}{c}\text { Sample } \\
\text { Type }\end{array}$ & Latitude & Longitude & 24K Quad & $\begin{array}{c}\text { Elevation } \\
\text { (ft.) }\end{array}$ & $\begin{array}{c}\text { Total } \\
\text { Depth } \\
\text { (ft.) }\end{array}$ \\
\hline 171 & W-16228 & Cuttings & 30.06635 & -81.53965 & ORANGEDALE & 29 & 610 \\
\hline 172 & W-16292 & Cuttings & 30.25361 & -81.58222 & ARLINGTON & 21 & 0 \\
\hline 173 & W-16293 & Cuttings & 30.04449 & -81.80428 & MIDDLEBURG & 87 & 983 \\
\hline 174 & W-16551 & Cuttings & 30.46829 & -81.57121 & EASTPORT & 24 & 798 \\
\hline 175 & W-17253 & Cuttings & 30.37821 & -81.84077 & DINSMORE & 92 & 45 \\
\hline 176 & W-17256 & Cuttings & 30.00611 & -81.69444 & FLEMING ISLAND & 21 & 32 \\
\hline 177 & W-17545 & Cuttings & 30.40250 & -81.92111 & BRYCEVILLE & 78 & 500 \\
\hline 178 & W-17548 & Cuttings & 30.40250 & -81.92111 & BRYCEVILLE & 78 & 42 \\
\hline 179 & W-17772 & Cuttings & 30.40250 & -81.92111 & BRYCEVILLE & 78 & 120 \\
\hline 180 & W-18259 & Cuttings & 30.04500 & -81.44945 & DURBIN & 42 & 81 \\
\hline 181 & W-18285 & Cuttings & 30.04500 & -81.44945 & DURBIN & 42 & 680 \\
\hline 182 & W-18366 & Cuttings & 30.12722 & -81.54417 & BAYARD & 20 & 200 \\
\hline 183 & W-18423 & Cuttings & 30.06000 & -81.83444 & MIDDLEBURG & 82 & 200 \\
\hline 184 & W-18468 & Cuttings & 30.47278 & -81.48695 & MAYPORT & 18 & 200 \\
\hline 185 & W-18517 & Cuttings & 30.47278 & -81.48695 & MAYPORT & 18 & 570 \\
\hline 186 & W-18617 & Cuttings & 30.11806 & -81.84861 & MIDDLEBURG & 65 & 540 \\
\hline 187 & W-18618 & Cuttings & 30.11829 & -81.84846 & MIDDLEBURG & 65 & 90 \\
\hline 188 & W-18818 & Cuttings & 30.48106 & -81.82429 & DINSMORE & 14 & 195 \\
\hline 189 & W-19218 & Core & 30.22917 & -81.70444 & ORANGE PARK & 10 & 124 \\
\hline 190 & W-19433 & Cuttings & 30.16444 & -81.39222 & PALM VALLEY & 5 & 410 \\
\hline
\end{tabular}

